\title{
Toward Orally Absorbed Prodrugs of the Antibiotic Aztreonam. Design of Novel Prodrugs of Sulfate Containing Drugs Part 2
}

Eric M. Gordon, * Matthew A. J. Duncton, Brian Wang, Longwu Qi, Dazhong Fan, Xianfeng Li, Zhi-Jie Ni, Pingyu Ding, Ruslan Grygorash, Eddy Low, Guiyun Yu, and Jiawei Sun

Arixa Pharmaceuticals, Inc., 525 University Avenue, Suite 1350, Palo Alto, CA 94301, United States of America

E.mail:emgordon@gmail.com

\section{Supporting Information}

\begin{tabular}{ll} 
CONTENTS & PAGE \\
\cline { 2 - 2 } GENERAL & S2-S3 \\
SYNTHESIS OF BETA-LACTAM INTERMEDIATE 12A & S4-S7 \\
ALTERNATIVE SYNTHESIS OF INTERMEDIATE 12A FROM FIGURE 4 & S8-S13 \\
SYNTHESIS OF BETA-LACTAM INTERMEDIATE 12B & S14-S15 \\
SYNTHESIS OF BETA-LACTAM INTERMEDIATE 12C & S16-S17 \\
SYNTHESIS OF FINAL PRODRUGS 27A TO 27C, 28A TO 28C AND 29B AND 29C S18-S26 \\
TABLE S1. RELEASE OF AZTREONAM FROM PRODRUG 28C USING CES1 & S27 \\
TABLE S3. RELEASE OF AZTREONAM FROM PRODRUG 29C USING CES1 & S28 \\
SYNTHESIS OF 3,3-DIMETHYLTETRAHYDROFURAN & S29 \\
${ }^{1}$ H-NMR STUDY 1: RELEASE OF 3,3-DIMETHYLTETRAHYDROFURAN AND & S30-S31 \\
AZTREONAM FROM COMPOUND 28C & \\
${ }^{1}$ H-NMR STUDY 2: RELEASE OF 5,5-DIMETHYLTETRAHYDRO-2H-PYRAN- & S32-S33 \\
2-ONE / 5-HYDROXY-4,4-DIMETHYLPENTANOIC ACID AND AZTREONAM & \\
FROM COMPOUND 29C & \\
REFERENCES & \\
&
\end{tabular}




\section{GENERAL}

All reagents were purchased from commercial suppliers and used without further purification. All solvents were reagent, or HPLC grade. Analytical TLC was performed on silica gel 60 F254 plates and visualized by UV if possible, or by staining with $\mathrm{KMnO}_{4}$ dip, or phosphomolybdic acid in EtOH dip. Flash chromatography was carried out using an automated system with pre-packed silica columns. Yields refer to isolated yields of pure compounds. ${ }^{1} \mathrm{H}$ NMR and ${ }^{13} \mathrm{C}$ NMR spectra were recorded on a $300 \mathrm{MHz}$ spectrometer at ambient temperature. Chemical shifts are reported in parts per million $(\mathrm{ppm})$ relative to deuterated solvent, or a TMS internal standard. Multiplicities are reported as follows: $\mathrm{s}=$ singlet; $\mathrm{d}=$ doublet, $\mathrm{t}=$ triplet; $\mathrm{m}=$ multiplet; $\mathrm{br}=$ broad; $\mathrm{f}=$ fine. High-resolution mass spectrometry was obtained on a Waters Xevo G2 QTOF with Acquity LC system. All final compounds are of $\geq 95 \%$ purity as assessed by ${ }^{1} \mathrm{H}$ and ${ }^{13} \mathrm{C}$ NMR, together with HPLC (20 minute method). Mass spectrometry and high-resolution mass-spectrometry (key compounds) were also used to assess final compounds.

\section{LC-MS 6 minute method:}

Autosampler: Finnigan Surveyor Autosampler Plus

MS Pump: Finnigan Surveyor MS Pump Plus

UV Detector: Finnigan Surveyor PDA Plus Detector

Mass Spectrometer: Finnigan LTQ

Ionization Method: APCI

Column: Phenomenex, Gemini $5 \mu \mathrm{m}$ C18 110Å, 50 x 3 mm

Solvent system:

Solvent A: water $+0.1 \%$ formic acid

Solvent B: $90 \%$ acetonitrile / $10 \%$ water $+0.1 \%$ formic acid

Gradient time table:

\begin{tabular}{|c|c|c|c|}
\hline Time (min) & $\begin{array}{c}\text { Flow } \\
(\mathbf{m L} / \mathbf{m i n})\end{array}$ & $\mathbf{\% A}$ & $\mathbf{\% B}$ \\
\hline 0.00 & 0.50 & 90.00 & 10.00 \\
\hline 0.10 & 0.50 & 90.00 & 10.00 \\
\hline 3.50 & 0.50 & 0.00 & 100.00 \\
\hline 4.50 & 0.50 & 0.00 & 100.00 \\
\hline 5.00 & 0.50 & 90.00 & 10.00 \\
\hline 6.00 & 0.50 & 90.00 & 10.00 \\
\hline
\end{tabular}




\section{LC-MS 10 minute method:}

Autosampler: Finnigan Surveyor Autosampler Plus

MS Pump: Finnigan Surveyor MS Pump Plus

UV Detector: Finnigan Surveyor PDA Plus Detector

Mass Spectrometer: Finnigan LTQ

Ionization Method: APCI

Column: Phenomenex, Gemini $5 \mu \mathrm{m}$ C18 110, 50 x 3 mm

Solvent system:

Solvent A: water $+0.1 \%$ formic acid

Solvent B: $90 \%$ acetonitrile / $10 \%$ water $+0.1 \%$ formic acid

Gradient time table:

\begin{tabular}{|c|c|c|c|}
\hline Time (min) & $\begin{array}{c}\text { Flow } \\
(\mathrm{mL} / \mathrm{min})\end{array}$ & $\% \mathrm{~A}$ & $\% \mathrm{~B}$ \\
\hline 0.00 & 0.50 & 90.00 & 10.00 \\
\hline 0.10 & 0.50 & 90.00 & 10.00 \\
\hline 7.50 & 0.50 & 0.00 & 100.00 \\
\hline 8.50 & 0.50 & 0.00 & 100.00 \\
\hline 9.00 & 0.50 & 90.00 & 10.00 \\
\hline 10.00 & 0.50 & 90.00 & 10.00 \\
\hline
\end{tabular}

HPLC 20 minute method: Used to assess purity of final compounds

Pump: Varian ProStar Model 210

UV Detector: Varian ProStar (Photo Diode Array)

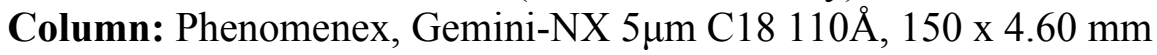

Solvent system:

Solvent A: water $+0.1 \%$ trifluoroacetic acid

Solvent B: acetonitrile

Gradient time table:

\begin{tabular}{|c|c|c|c|}
\hline Time (min) & $\begin{array}{c}\text { Flow } \\
(\mathbf{m L} / \mathbf{m i n})\end{array}$ & $\mathbf{\% A}$ & $\mathbf{\% B}$ \\
\hline Prerun & 1.20 & 90.00 & 10.00 \\
\hline 1.00 & 1.20 & 90.00 & 10.00 \\
\hline 16.00 & 1.20 & 10.00 & 90.00 \\
\hline 22.00 & 1.20 & 10.00 & 90.00 \\
\hline 22.50 & 1.20 & 90.00 & 10.00 \\
\hline
\end{tabular}




\section{SYNTHESIS OF BETA-LACTAM INTERMEDIATE 12A}
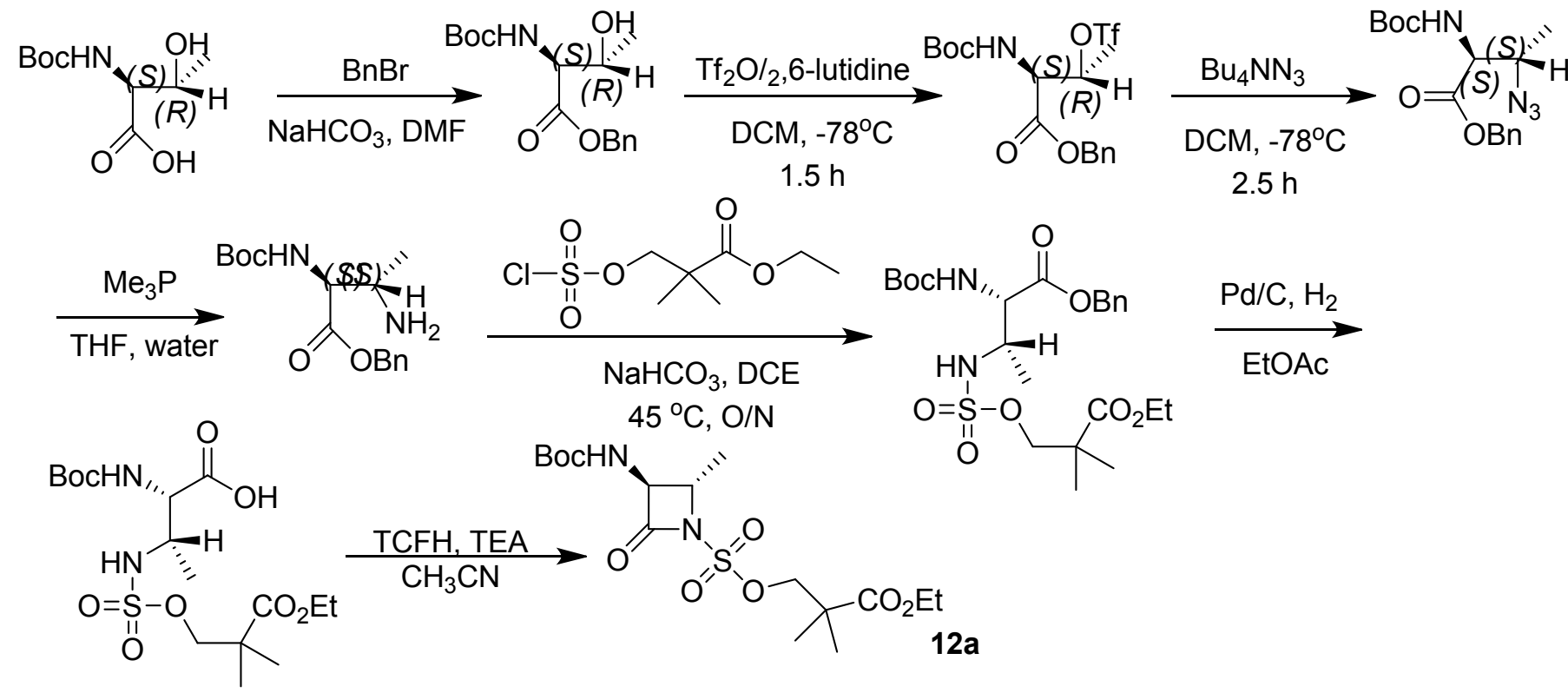

\section{Preparation of 2-tert-butoxycarbonylamino-3-hydroxy-butyric acid benzyl ester 5}

To a solution of Boc-L-Threonine $(15.0 \mathrm{~g}, 68.4 \mathrm{mmol})$ in DMF $(465 \mathrm{~mL})$ at $0^{\circ} \mathrm{C}$ were added $\mathrm{NaHCO}_{3}(16.0 \mathrm{~g}, 190.2 \mathrm{mmol})$ and benzyl bromide (40.6 mL, $\left.342.1 \mathrm{mmol}\right)$. After stirring overnight at rt, water was added and the mixture was extracted with EtOAc. The organic layers were washed with water and brine, and concentrated. The dried residue was purified with flash chromatography over silica gel (0-60\%, EtOAc / Hexanes) to obtain the title compound $\mathbf{5}$ ( $18.8 \mathrm{~g}, 89 \%$ yield) as a colorless oil.

${ }^{1} \mathrm{H}$ NMR (300 MHz, $\left.\mathrm{CDCl}_{3}\right)$ \& 7.43-7.29 (m, 5H), $5.35(\mathrm{~d}, J=9.2 \mathrm{~Hz}, 1 \mathrm{H}), 5.32-5.11(\mathrm{~m}$, 2H), 4.29 (d, $J=9.4 \mathrm{~Hz}, 2 \mathrm{H}), 1.44$ (s, 9H), 1.31-1.19 (m, 3H).

\section{LC-MS: $310[\mathrm{M}+\mathrm{H}]^{+}$}

\section{Preparation of 3-azido-2-tert-butoxycarbonylamino-butyric acid benzyl ester 7}

To a solution of 2-tert-butoxycarbonylamino-3-hydroxy-butyric acid benzyl ester 5 (9.28 $\mathrm{g}, 30.0 \mathrm{mmol}, 1.0 \mathrm{eq})$ in anhydrous dichloromethane $(150 \mathrm{~mL})$ at $-78{ }^{\circ} \mathrm{C}$ were added trifluoromethanesulfonic anhydride $(6.06 \mathrm{~mL}, 36.0 \mathrm{mmol}, 1.2 \mathrm{eq})$ dropwise and 2,6lutidine $(4.54 \mathrm{~mL}, 39.0 \mathrm{~mL}, 1.3 \mathrm{eq})$ respectively. The reaction was stirred at the same temperature for $1.5 \mathrm{~h} . \mathrm{Bu}_{4} \mathrm{NN}_{3}(21.3 \mathrm{~g}, 75.0 \mathrm{mmol}, 2.5 \mathrm{eq})$ in anhydrous dichloromethane $(30 \mathrm{~mL})$ was added. The mixture was stirred at $-78{ }^{\circ} \mathrm{C}$ for $1 \mathrm{~h}$ and the reaction was warmed to room temperature for $1.5 \mathrm{~h}$. The reaction mixture was diluted 
with dichloromethane and washed with saturated sodium bicarbonate. The organic phase was separated, dried over sodium sulfate, and concentrated to dryness. The residue was purified by flash chromatography (silica, Hexanes $/$ EtOAc $=4: 1$ ) to give the title compound $7(8.82 \mathrm{~g}, 88 \%)$ as a colorless oil.

${ }^{1} \mathrm{H}$ NMR $\left(300 \mathrm{MHz}, \mathrm{CDCl}_{3}\right) \delta 7.61(\mathrm{~s}, 1 \mathrm{H}), 7.36(\mathrm{~d}, J=2.6 \mathrm{~Hz}, 4 \mathrm{H}), 5.29(\mathrm{~s}, 1 \mathrm{H}), 5.29-$

$5.11(\mathrm{~m}, 2 \mathrm{H}), 4.46(\mathrm{~d}, J=8.5 \mathrm{~Hz}, 1 \mathrm{H}), 3.84(\mathrm{~d}, J=8.1 \mathrm{~Hz}, 1 \mathrm{H}), 1.45(\mathrm{~d}, J=0.8 \mathrm{~Hz}, 9 \mathrm{H})$, $1.34-1.16(\mathrm{~m}, 3 \mathrm{H})$;

${ }^{13} \mathrm{C}$ NMR (75 MHz, $\left.\mathrm{CDCl}_{3}\right)$ \&: 169.5, 155.0, 134.9, 128.7, 128.6, 128.5, 80.5, 67.6, 58.8, $57.5,28.3,28.3,15.4$.

\section{Preparation of 3-amino-2-tert-butoxycarbonylamino-butyric acid benzyl ester 8}

To a solution of 3-azido-2-tert-butoxycarbonylamino-butyric acid benzyl ester 7 (11.3 g, $33.8 \mathrm{mmol}, 1.0 \mathrm{eq})$ in tetrahydrofuran $(40 \mathrm{~mL})$ was added trimethylphosphine $(1.0 \mathrm{M}$ in THF, $67.6 \mathrm{mmol}, 67.6 \mathrm{mmol}, 2.0 \mathrm{eq})$ at $0{ }^{\circ} \mathrm{C}$. The reaction was warmed to room temperature for $2 \mathrm{~h}$. Water $(4 \mathrm{~mL})$ was added to the reaction and the mixture was stirred at room temperature for $2 \mathrm{~h}$. The reaction mixture was concentrated to dryness. The residue was purified by flash chromatography (silica, EtOAc) to give the title compound $8(8.05 \mathrm{~g}, 77 \%)$ as a colorless oil.

${ }^{1} \mathrm{H}$ NMR $\left(300 \mathrm{MHz}, \mathrm{CDCl}_{3}\right) \delta 7.36(\mathrm{t}, J=1.5 \mathrm{~Hz}, 5 \mathrm{H}), 7.26(\mathrm{~s}, 1 \mathrm{H}), 5.30(\mathrm{~m}, 1 \mathrm{H}), 5.28-$ $5.10(\mathrm{~m}, 2 \mathrm{H}), 4.32(\mathrm{~s}, 1 \mathrm{H}), 3.30(\mathrm{~s}, 1 \mathrm{H}), 1.47(\mathrm{~s}, 9 \mathrm{H}), 1.02(\mathrm{~d}, J=6.7 \mathrm{~Hz}, 3 \mathrm{H})$.

LC-MS: $309[\mathrm{M}+\mathrm{H}]^{+}$

Preparation of 2-tert-butoxycarbonylamino-3-(2-ethoxycarbonyl-2-methylpropoxysulfonyl amino)-butyric acid benzyl ester 10a

To a solution of 3-amino-2-tert-butoxycarbonylamino-butyric acid benzyl ester 8 (4.09 g, $13.3 \mathrm{mmol}, 1.0 \mathrm{eq})$ in 1,2-dichloroethane $(50 \mathrm{~mL})$ was added a saturated aqueous solution of sodium bicarbonate $(50 \mathrm{~mL})$. To the mixture was added ethyl 3-((chlorosulfonyl)oxy)2,2-dimethylpropanoate 9a (6.49 g, $26.2 \mathrm{mmol}, 2.0 \mathrm{eq})$ and the mixture was stirred rapidly at $45^{\circ} \mathrm{C}$ for $20 \mathrm{~h}$. The reaction mixture was cooled to room temperature and the layers were separated. The organic layer was dried with anhydrous sodium sulfate and concentrated to dryness. The residue was purified by flash column chromatography ( silica, Hexanes / EtOAc $=3: 1)$ to give the title compound $10 \mathrm{a}(5.07 \mathrm{~g}, 74 \%)$ as a solid. 
${ }^{1} \mathrm{H}$ NMR $\left(300 \mathrm{MHz}, \mathrm{CDCl}_{3}\right) \delta$ 7.37-7.27 (m, 5H), 6.03-5.96 (m, 1H), 5.52-5.46 (m, 1H), $5.18(\mathrm{~s}, 2 \mathrm{H}), 4.57-4.52(\mathrm{~m}, 1 \mathrm{H}), 4.18-4.07(\mathrm{~m}, 4 \mathrm{H}), 4.01-3.95(\mathrm{~m}, 1 \mathrm{H}), 1.42(\mathrm{~s}, 9 \mathrm{H}), 1.33-$ $1.22(\mathrm{~m}, 9 \mathrm{H}), 1.16(\mathrm{~d}, J=6.7 \mathrm{~Hz}, 3 \mathrm{H})$.

${ }^{13} \mathrm{C} \mathrm{NMR}\left(75 \mathrm{MHz}, \mathrm{CDCl}_{3}\right) \delta 174.8,169.6,134.7,128.8,128.7,128.5,81.0,75.3,67.9$, $61.0,57.7,53.4,52.8,42.6,28.2,22.1,16.6,14.1$.

\section{Preparation of 2-tert-butoxycarbonylamino-3-(2-ethoxycarbonyl-2-methyl-} propoxysulfonyl-amino)-butyric acid 11 a

To a solution of 2-tert-butoxycarbonylamino-3-(2-ethoxycarbonyl-2-methylpropoxysulfonyl amino)-butyric acid benzyl ester 10a (4.20 g, $8.14 \mathrm{mmol}, 1.0 \mathrm{eq})$ in ethyl acetate $(50 \mathrm{~mL})$ was added $\mathrm{Pd} / \mathrm{C}(420 \mathrm{mg})$. The suspension was degassed 3 times and refilled with hydrogen. The mixture was stirred at room temperature for $2 \mathrm{~h}$. The reaction mixture was filtered though a pad of Celite. The filtrate was concentrated to dryness, affording the title compound $11 \mathrm{a}(3.47 \mathrm{~g}, 100 \%)$.

${ }^{1} \mathrm{H}$ NMR $\left(300 \mathrm{MHz}, \mathrm{CDCl}_{3}\right) \delta$ 6.23-1.18 (m, 1H), 5.68-5.63 (m, 1H), 4.45-4.40 (m, 1H), 4.19-4.05 (m, 4H), 3.97-3.89 (m, 1H), 1.50 (s, 9H), 1.39-1.22 (m, 12H).

${ }^{13} \mathrm{C}$ NMR (75 MHz, acetone- $\left.d 6\right) \delta 174.3,170.8,156.1,79.0,74.8,60.5,59.8,57.8,44.2$, 27.6, 21.5, 21.4, 21.4, 16.1, 13.6, 13.6.

LC-MS: $427[\mathrm{M}+\mathrm{H}]^{+}$

Preparation of 3-(3-tert-butoxycarbonylamino-2-methyl-4-oxo-azetidine-1sulfonyloxy)-2,2-dimethyl-propionic acid ethyl ester 12 a

To a solution of 2-tert-butoxycarbonylamino-3-(2-ethoxycarbonyl-2-methylpropoxysulfonyl-amino)-butyric acid $11 \mathrm{a}(3.47 \mathrm{~g}, 8.14 \mathrm{mmol}, 1.0 \mathrm{eq})$ in acetonitrile (240 $\mathrm{mL}$ ) was added $N, N, N^{\prime}, N^{\prime}$-tetramethylchloroformamidinium hexafluorophosphate [TCFH] (3.43 g, $12.2 \mathrm{mmol}, 1.5 \mathrm{eq})$ and triethylamine $(2.95 \mathrm{~mL}, 21.2 \mathrm{mmol}, 2.6 \mathrm{eq})$ a 0 ${ }^{\circ} \mathrm{C}$. The reaction was stirred at $0{ }^{\circ} \mathrm{C}$ for $10 \mathrm{~min}$ and concentrated to dryness. The residue was diluted to ethyl acetate and washed with water and brine. The organic phase was separated, dried, and concentrated to dryness. The residue was purified by flash column chromatography (silica, Hexanes / EtOAc $=3: 2$ ) to give the title compound $(2.97 \mathrm{~g}$, $89 \%)$. 
${ }^{1} \mathrm{H}$ NMR (300 MHz, acetone- $\left.d_{6}\right) \delta$ 7.05-6.97 (m, 1H), 4.56-4.51 (m, 1H), 4.49-4.40 (m, $3 \mathrm{H}), 4.17$ (dd, $J=7.5,6.9 \mathrm{~Hz}, 2 \mathrm{H}), 1.55(\mathrm{~d}, J=6.6 \mathrm{~Hz}, 3 \mathrm{H}), 1.42$ (s, 9H), 1.33-1.22 (m, $9 \mathrm{H})$.

${ }^{13} \mathrm{C}$ NMR $\left(75 \mathrm{MHz}\right.$, acetone- $\left.d_{6}\right) \delta 174.1,164.1,156.1,79.9,76.9,64.6,60.6,59.1,42.4$, 27.5, 21.3, 21.1, 16.7, 13.5 .

LC-MS: $409[\mathrm{M}+\mathrm{H}]^{+}$

${ }^{1} \mathrm{H}$ NMR $\left(300 \mathrm{MHz}, \mathrm{CDCl}_{3}\right) \delta 5.82(\mathrm{~d}, J=8.7 \mathrm{~Hz}, 1 \mathrm{H}), 4.54(\mathrm{~d}, J=10.2 \mathrm{~Hz}, 1 \mathrm{H}), 4.45$ (dd, $J=8.9 \mathrm{~Hz}, 3.5 \mathrm{~Hz}, 1 \mathrm{H}), 4.24-4.11(\mathrm{~m}, 4 \mathrm{H}), 1.58$ (d, $J=5.7 \mathrm{~Hz}, 3 \mathrm{H}), 1.42$ (s, 9H), 1.29-1.24 (m, 9H).

${ }^{13} \mathrm{C} \mathrm{NMR}\left(75 \mathrm{MHz}, \mathrm{CDCl}_{3}\right) \delta 175.6,165.2,154.6,81.0,77.2,64.5,61.6,60.7,42.8,28.3$, $22.1,21.8,18.0,14.1$. 


\section{ALternatiVe SYNTHESIS OF BETA-LACTAM 12A FROM FigURE 4}

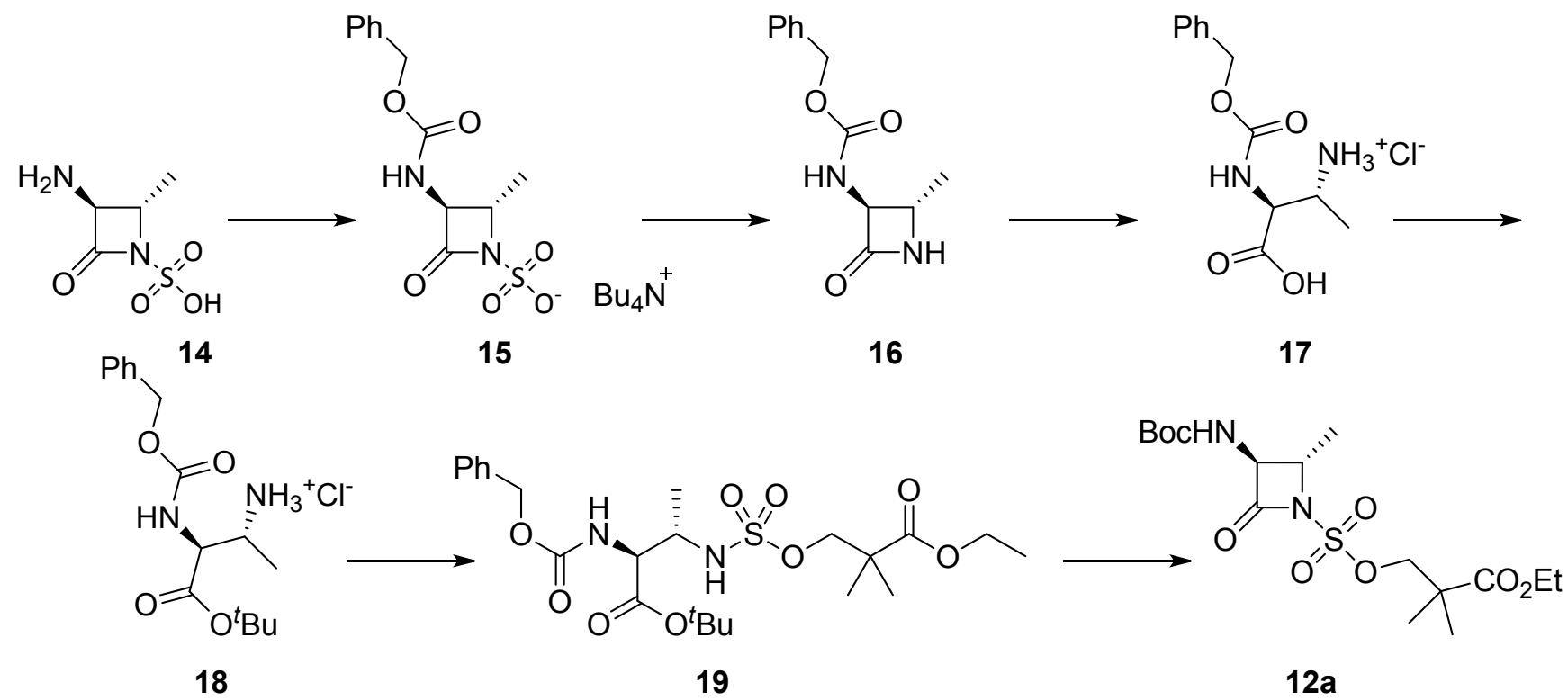

Preparation of tetrabutylammonium (2S, 3S)-3-(((benzyloxy)carbonyl)amino)-2methyl-4-oxoazetidine-1-sulfonate 15

To a solution of $(2 S, 3 S)$-3-amino-2-methyl-4-oxo-1-azetidinesulfonic acid (55.0 g, 305.2 mmol) in a mixture of EtOH $(600 \mathrm{~mL})$ and $\mathrm{H}_{2} \mathrm{O}(300 \mathrm{~mL})$ was added $\mathrm{Et}_{3} \mathrm{~N}(159.5 \mathrm{~mL}$, $915.7 \mathrm{mmol}$ ) followed by benzyloxycarbonyl $N$-succinimide $(83.7 \mathrm{~g}, 335.8 \mathrm{mmol})$. The reaction mixture was stirred at $\mathrm{rt}$ for 16 hours. Ethanol was removed under vacuum and the residue was diluted with $\mathrm{H}_{2} \mathrm{O}(200 \mathrm{~mL})$. The aqueous layer was extracted with EtOAc (2 x $100 \mathrm{~mL})$. The EtOAc was discarded. Tetrabutyl ammonium hydroxide (207.9 g, $320.5 \mathrm{mmol}$ ) as $40 \% \mathrm{w} / \mathrm{v}$ in $\mathrm{H}_{2} \mathrm{O}$ was added and the resulting aqueous layer was extracted with $\mathrm{CHCl}_{3}(5 \times 150 \mathrm{~mL})$. The organic extract was dried $\left(\mathrm{MgSO}_{4}\right)$ and concentered to give the product $(160 \mathrm{~g}, 94 \%)$ as a solid.

${ }^{1} \mathrm{H}-\mathrm{NMR}\left(300 \mathrm{MHz}, \mathrm{CDCl}_{3}\right) \delta 7.38-7.31(\mathrm{~m}, 5 \mathrm{H}), 4.31(\mathrm{~d}, J=7.2 \mathrm{~Hz}, 1 \mathrm{H}), 6.01(\mathrm{~s}, 2 \mathrm{H})$ $5.50(\mathrm{~s}, 1 \mathrm{H}), 5.12(\mathrm{~s}, 2 \mathrm{H}), 4.31(\mathrm{~d}, J=7.2 \mathrm{~Hz}, 1 \mathrm{H}), 3.28-3.22(\mathrm{~m}, 8 \mathrm{H}), 1.62-1.59(\mathrm{~m}, 8 \mathrm{H})$, $1.46-1.39(\mathrm{~m}, 11 \mathrm{H}), 1.01-0.96(\mathrm{~m}, 12 \mathrm{H})$

${ }^{13} \mathrm{C}-\mathrm{NMR}\left(75 \mathrm{MHz}, \mathrm{CDCl}_{3}\right) \delta 162.9,155.7,136.1,135.7,128.5,128.3,128.2,128.0$, $67.0,62.7,59.2,58.5,23.9,19.6,18.2,13.7$. 


\section{Preparation of benzyl ((2S, 3S)-2-methyl-4-oxoazetidin-3-yl)carbamate 16}

$(2 S$,

3S)-3-(((benzyloxy)carbonyl)amino)-2-methyl-4-oxoazetidine-1-sulfonate tetrabutylammonium salt (131 g, $235.7 \mathrm{mmol}$ ) was dissolved in dry THF $(2.8 \mathrm{~L})$ and $\mathrm{H}_{2} \mathrm{O}$ (12.8 $\mathrm{mL}, 710.5 \mathrm{mmol})$, then the resulting solution was cooled in an ice bath. Trifluoroacetic acid $(280 \mathrm{~mL})$ was added dropwise, and the mixture was stirred at room temperature for 1.5 hours. The reaction mixture was concentrated under vacuum, and the residue was diluted with DCM $(1.5 \mathrm{~L})$, then chilled with an ice bath. $10 \%$ Aqueous $\mathrm{NaOH}$ solution was added slowly until $\mathrm{pH}=8-9$. The organic layer was washed with $\mathrm{H}_{2} \mathrm{O}$, dried $\left(\mathrm{MgSO}_{4}\right)$ and concentered under vacuum. The residue was purified by column chromatography on silica gel using EtOAc / hexanes (1:9 to 1:0) to give the product (30.1 $\mathrm{g}, 54 \%)$ as a solid.

${ }^{1} \mathrm{H}-\mathrm{NMR}\left(300 \mathrm{MHz}, \mathrm{CDCl}_{3}\right) \delta$ 7.38-7.31 (m, 5H), $6.01(\mathrm{~s}, 1 \mathrm{H}) 5.50(\mathrm{~s}, 1 \mathrm{H}), 5.12(\mathrm{~s}, 2 \mathrm{H})$, $4.31(\mathrm{~d}, J=7.2 \mathrm{~Hz}, 1 \mathrm{H}), 3.74-3.71(\mathrm{~m}, 1 \mathrm{H}), 1.42(\mathrm{~d}, J=6 \mathrm{~Hz}, 3 \mathrm{H})$

${ }^{13} \mathrm{C}-\mathrm{NMR}\left(75 \mathrm{MHz}, \mathrm{CDCl}_{3}\right) \delta 167.4,155.9,136.1,67.2,64.7,54.0,19.2$.

LC-MS: $m / z=280.1\left[\mathrm{M}+\mathrm{HCO}_{2} \mathrm{H}\right]^{+}$

Preparation of (2S, 3R)-3-amino-2-(((benzyloxy)carbonyl)amino)butanoic acid $\mathrm{HCl}$ salt 17

Benzyl ((2S, 3S)-2-methyl-4-oxoazetidin-3-yl)carbamate azetidin-3-yl)carbamate (6.0 g, $25.6 \mathrm{mmol})$ was dissolved in neat formic acid $(50 \mathrm{~mL}) . \mathrm{H}_{2} \mathrm{O}(50 \mathrm{~mL})$ was added and the resulting mixture was stirred at $\mathrm{rt}$ for 18 hours. The mixture was concentrated under vacuum to give $(2 S, 3 R)$-3-amino-2-(((benzyloxy)carbonyl)amino)butanoic formic acid salt as a solid. The formic acid salt was dissolved in $\mathrm{MeCN}(10 \mathrm{~mL}) .4 \mathrm{~N} \mathrm{HCl}$ in dioxane $(15 \mathrm{~mL})$ was added and the resulting solution was concentrated to dryness under vacuum. Another portion of $4 \mathrm{~N} \mathrm{HCl}$ in dioxane $(15 \mathrm{~mL})$ was added and the mixture was stirred for 1 hour at $\mathrm{rt}-\mathrm{a}$ solid formed. $\mathrm{Et}_{2} \mathrm{O}(50 \mathrm{~mL})$ was added and the solid was collected by filtration to give the product ( $6.8 \mathrm{~g}, 92 \%)$.

${ }^{1} \mathrm{H}-\mathrm{NMR}\left(300 \mathrm{MHz}, \mathrm{CD}_{3} \mathrm{OD}\right) \delta 7.59(\mathrm{~d}, J=8.7 \mathrm{~Hz}, 1 \mathrm{H}), 7.41-7.30(\mathrm{~m}, 5 \mathrm{H}), 5.15(\mathrm{q}, J=$ $21 \mathrm{~Hz}, 2 \mathrm{H}), 4.68-4.64(\mathrm{~m}, 1 \mathrm{H}), 3.88-3.84(\mathrm{~m}, 1 \mathrm{H}), 1.25(\mathrm{~d}, J=7.2 \mathrm{~Hz}, 3 \mathrm{H})$. 
${ }^{13} \mathrm{C}$ NMR (75 MHz, $\left.\mathrm{CD}_{3} \mathrm{OD}\right) \delta 171.4,159.1,137.8,129.5,129.1,129.0,68.3,56.9,49.9$, 14.1.

LC-MS: $m / z=253.3[\mathrm{M}+\mathrm{H}]^{+}$

Preparation of tert-butyl (2S, 3R)-3-amino-2-(((benzyloxy)carbonyl)-amino)butanoate 18

To a solution of (2S, 3S)-3-amino-2-(((benzyloxy)carbonyl)amino)butanoic acid hydrochloride $(4.5 \mathrm{~g}, 15.5 \mathrm{mmol})$ in 1,4 -dioxane $(36 \mathrm{~mL})$ at $-10{ }^{\circ} \mathrm{C}$ was added dropwise concentrated $\mathrm{H}_{2} \mathrm{SO}_{4}(4.9 \mathrm{ml}, 92.8 \mathrm{mmol})$. The reaction mixture was placed in a dry iceacetone bath and iso-butylene ( $36 \mathrm{~g}, 622.5 \mathrm{mmol}$ ) was added. The reaction vessel was capped, and the reaction mixture was stirred at $\mathrm{rt}$ for 48 hours. Iso-butylene was removed by passing nitrogen through the solution, and the mixture was poured into a mixture of $\mathrm{H}_{2} \mathrm{O}(150 \mathrm{~mL})$ and saturated aqueous $\mathrm{Na}_{2} \mathrm{CO}_{3}(50 \mathrm{~mL})$. The aqueous layer was extracted with EtOAc ( $3 \times 100 \mathrm{~mL})$, and the combined organic layers were washed with brine (50 $\mathrm{mL})$, dried $\left(\mathrm{MgSO}_{4}\right)$ and concentered under vacuum. The residue was purified by column chromatography on silica gel using DCM / MeOH (1:0 to 9:1) to the product (2.83 g, $59 \%)$ as a clear oil.

${ }^{1} \mathrm{H} \mathrm{NMR}\left(300 \mathrm{MHz}, \mathrm{CDCl}_{3}\right) \delta 7.37-7.31(\mathrm{~m}, 5 \mathrm{H}), 5.52(\mathrm{~d}, J=6.9 \mathrm{~Hz}, 1 \mathrm{H}), 5.11(\mathrm{~s}, 2 \mathrm{H})$, 4.28-4.24 (m, 1H), 3.33-3.30 (m, 1H), $1.46(\mathrm{~s}, 9 \mathrm{H}), 1.05(\mathrm{~d}, J=6.9 \mathrm{~Hz}, 3 \mathrm{H})$.

${ }^{13} \mathrm{C}$ NMR $\left(75 \mathrm{MHz}, \mathrm{CDCl}_{3}\right) \delta 170.0,156.7,136.3,128.6,128.3,128.2,82.5,67.1,60.5$, 49.5, 28.1, 18.9 .

LC-MS: $m / z=309.6[\mathrm{M}+\mathrm{H}]^{+}$

Alternative preparation of tert-butyl (2S, 3R)-3-amino-2-(((benzyloxy)carbonyl)amino)butanoate 18

A reactor equipped with a mechanical stirrer was prepared and flushed with Argon. Under Argon, (2S,3S)-3-amino-2-(((benzyloxy)carbonyl)amino)butanoic acid hydrochloride (28.77 g, $0.10 \mathrm{~mol})$ and tert-butyl acetate $(288 \mathrm{~mL}, 2.15 \mathrm{~mol}, 21.5 \mathrm{eq})$ were added to the reactor, stirred mechanically, and cooled in an ice bath. $\mathrm{H}_{2} \mathrm{SO}_{4}(12.1 \mathrm{~g}$, $0.12 \mathrm{~mol}, 1.20 \mathrm{eq}$ ) was dripped in over 10 minutes. The resulting slurry was immersed in a $20{ }^{\circ} \mathrm{C}$ bath for 10 minutes, then $\mathrm{AcOH}(72 \mathrm{~mL})$ was dripped in over 20 minutes. After 
17 hours, the homogeneous reaction solution was cooled with an ice bath while dripping in a solution of $\mathrm{NaOH}(96.8 \mathrm{~g})$ in $\mathrm{H}_{2} \mathrm{O}(450 \mathrm{~mL})$. The resulting solution was extracted with EtOAc $(600 \mathrm{~mL})$. The extract was washed with brine, dried $\left(\mathrm{Na}_{2} \mathrm{SO}_{4}\right)$, and concentrated to give the product (14.95 g). Data as above.

Preparation of tert-butyl (2S,3S)-2-(((benzyloxy)carbonyl)amino)-3-(((3-ethoxy-2,2dimethyl-3-oxopropoxy)sulfonyl)amino)butanoate 19

(2S,3S)-tert-butyl 3-amino-2-(((benzyloxy)carbonyl)amino)butanoate 1 (8.90 g, 28.9 mmol) was dissolved in 1,2-dichloroethane $(150 \mathrm{~mL})$ and combined with ethyl 3((chlorosulfonyl)oxy)-2,2-dimethylpropanoate (10.40 g, $37.4 \mathrm{mmol})$. This solution was combined in a round-bottomed flask with $200 \mathrm{~mL}$ of saturated aq. sodium bicarbonate. A stir bar was added and the flask sealed with a rubber septum into which a needle connected to a balloon containing Argon was introduced. The mixture was heated in a 40 ${ }^{\circ} \mathrm{C}$ and stirred rapidly for 46 hours. Stirring was stopped, the phases were partitioned, and the aq. phase was extracted with DCM $(50 \mathrm{~mL})$. The organic phases were combined, dried with sodium sulfate, and concentrated to an oil $(17.0 \mathrm{~g})$. The oil was purified by column chromatography on silica gel (330-g column) using $\mathrm{Et}_{2} \mathrm{O} /$ Hexanes (1:9 to 2:3) as eluent [monitoring for absorbances at $210-\mathrm{nM}$ ] to give pure product $(6.40 \mathrm{~g})$, together with impure fractions $(3.15 \mathrm{~g})$. A significant amount of non-transformed starting material remained on top of the column. This was recovered by washing the column with $\mathrm{MeOH} /$ DCM (1:9) as eluent to give starting material $(2.27 \mathrm{~g})$. The impure fractions (3.15 g) from the column were re-purified to provide additional pure product $(2.17 \mathrm{~g})$. Considering recovery of starting material, the percent yield of this reaction is $77 \%$.

${ }^{1} \mathrm{H}$ NMR $\left(300 \mathrm{MHz}, \mathrm{CDCl}_{3}\right) \delta$ 7.38-7.33 (m, 5H), $6.02(\mathrm{~d}, J=7.5 \mathrm{~Hz}, 1 \mathrm{H}), 5.73(\mathrm{~d}, J=$ $5.7 \mathrm{~Hz}, 1 \mathrm{H}), 5.13$ (s, 2H), 4.50 (dd, $J=7.1,5.7 \mathrm{~Hz}, 1 \mathrm{H}), 4.20-4.11$ (m, 4H), 3.99-3.95 (m, $1 \mathrm{H}), 1.47$ (s, 9H), $1.27-1.23$ (m, 9H), 1.17 (d, $J=6.6 \mathrm{~Hz}, 3 \mathrm{H})$.

${ }^{13} \mathrm{C}$ NMR (75 MHz, $\left.\mathrm{CDCl}_{3}\right) \delta 174.9,168.5,157.3,135.8,128.7,128.5,128.4,84.0,75.4$, $67.8,61.2,58.5,53.0,42.8,28.0,22.2,16.5,14.2$.

LC-MS: $517.0[\mathrm{M}+\mathrm{H}]^{+}$ 
Preparation of 3-(3-tert-butoxycarbonylamino-2-methyl-4-oxo-azetidine-1sulfonyloxy)-2,2-dimethyl-propionic acid ethyl ester $12 a$

Into a reactor equipped with a bubbler and an inlet of Argon was added tert-butyl $(2 S, 3 S)-2-((($ benzyloxy)carbonyl)amino)-3-(((3-ethoxy-2,2-dimethyl-3-oxopropoxy)

sulfonyl)amino)butanoate $(15.29 \mathrm{~g}, 30.0 \mathrm{mmol})$. An Argon atmosphere was established and anhydrous MeCN (460 mL) was added, stirring to dissolve. The resulting solution was cooled in an ice bath while $4 \mathrm{M} \mathrm{HCl}$ in 1,4-dioxane (153 mL, $612 \mathrm{mmol}, 20.7 \mathrm{eq})$ was added dropwise over 20 minutes. The reaction mixture was heated at $40{ }^{\circ} \mathrm{C}$ and stirred for $2 \mathrm{hr}$ [note: a constant stream of Argon passing into and out of the reactor for the duration of the reaction]. The solution was concentrated on a rotary evaporator then re-concentrated with $\mathrm{MeCN}(150 \mathrm{~mL})$ and re-evaporated. This procedure was repeated $\mathrm{x}$ 4. The crude, de-tert-butylated product $(15.51 \mathrm{~g})$ was used without further purification. ${ }^{1} \mathrm{H}$ NMR $\left(300 \mathrm{MHz}, \mathrm{CDCl}_{3}\right) \delta$ 7.38-7.32 (m, 5H), $6.07(\mathrm{~d}, J=7.5 \mathrm{~Hz}, 1 \mathrm{H}), 5.91(\mathrm{~d}, J=$ $6.6 \mathrm{~Hz}, 1 \mathrm{H}), 5.14(\mathrm{~s}, 2 \mathrm{H}), 4.63-4.61(\mathrm{~m}, 1 \mathrm{H}), 4.24-4.05(\mathrm{~m}, 4 \mathrm{H}), 3.93(\mathrm{~m}, 1 \mathrm{H}), 1.30-1.24$ $(\mathrm{m}, 12 \mathrm{H})$.

\section{LCMS: $460.97[\mathrm{M}+\mathrm{H}]^{+}$}

The crude de-tert-butylated product above (10.38 g used in this step) was combined with $10 \%$ palladium-on-carbon $\left[50 \% \mathrm{w} / \mathrm{w}\right.$ with $\left.\mathrm{H}_{2} \mathrm{O}\right](2.33 \mathrm{~g})$ and $\mathrm{MeOH}(120 \mathrm{~mL})$ in a round-bottomed flask equipped with a stir bar. The mixture was placed under an atmosphere of hydrogen and the solution stirred for $1 \mathrm{hr}$. The mixture was filtered and the filter cake was washed with $\mathrm{MeOH}(80 \mathrm{~mL})$. The filtrate was concentrated under vacuum and dried further in a vacuum oven set to $60{ }^{\circ} \mathrm{C}$ to give a crude amino-acid product $(7.21 \mathrm{~g})$ that was used without further purification.

${ }^{1} \mathrm{H}$ NMR (300 MHz, $d_{6}$-DMSO) $\delta 7.97(\mathrm{~s}, 3 \mathrm{H}), 4.12-3.97(\mathrm{~m}, 4 \mathrm{H}), 3.87-3.84(\mathrm{~m}, 1 \mathrm{H})$, $3.45(\mathrm{~d}, J=1.8 \mathrm{~Hz}, 1 \mathrm{H}), 1.18-1.14(\mathrm{~m}, 9 \mathrm{H}), 1.07$ (d, $J=6.9 \mathrm{~Hz}, 3 \mathrm{H})$

${ }^{13} \mathrm{C}$ NMR $\left(75 \mathrm{MHz}, d_{6}\right.$-DMSO) $\delta 174.3,169.0,74.5,60.6,58.4,50.3,42.2,21.8,21.7$, 14.7, 14.0 .

LC-MS (ESI): $327.2[\mathrm{M}+\mathrm{H}]^{+}$

This crude amino-acid product above (7.38 g) was combined with di-tert-butyl dicarbonate and tetrahydrofuran $(120 \mathrm{~mL})$. To this stirred solution was added $\mathrm{Et}_{3} \mathrm{~N}(7.9$ 
$\mathrm{mL}$ ) and a balloon of Argon was placed above the reaction. The mixture was stirred at 40 ${ }^{\circ} \mathrm{C}$ for $4 \mathrm{hr}$. The mixture was concentrated under vacuum, then mixed with $\mathrm{H}_{2} \mathrm{O}(150 \mathrm{~mL})$ and extracted with hexanes $(150 \mathrm{~mL})$. The aqueous phase was combined with EtOAc $(150 \mathrm{~mL})$ and stirred vigorously while $7.90 \mathrm{~g}$ of citric acid was added in one portion. The aqueous and organic layers were partitioned, and the aqueous phase was extracted with EtOAc $(150 \mathrm{~mL})$. The combined organic layers were dried $\left(\mathrm{Na}_{2} \mathrm{SO}_{4}\right)$, filtered and concentrated under vacuum. The product was dried further in a vacuum oven (set at 55 $\left.{ }^{\circ} \mathrm{C}\right)$ to give the product $(9.0 \mathrm{~g})$ that was used without further purification.

LC-MS: $426.7[\mathrm{M}+\mathrm{H}]^{+}$

The crude Boc-amino acid from above (5.18 $\mathrm{g}$ of the sample) was dissolved in anhydrous $\mathrm{MeCN}(300 \mathrm{~mL})$ and placed under an atmosphere of Argon. The solution was stirred and cooled in an ice-water bath for $5 \mathrm{~min}$, then $N, N, N^{\top}, N^{\prime}$-tetramethylchloroformamidinium hexafluorophosphate $[\mathrm{TCFH}](4.77 \mathrm{~g}, 17.0 \mathrm{mmol})$ was added in one portion. The mixture was stirred in the ice bath for $30 \mathrm{~min}$, then at room temperature for an additional $15 \mathrm{~min}$. The mixture was concentrated under vacuum. The residue was mixed with $\mathrm{H}_{2} \mathrm{O}(40 \mathrm{~mL})$ and extracted with EtOAc $(3 \times 50 \mathrm{~mL})$. The combined organic extracts were dried $\left(\mathrm{Na}_{2} \mathrm{SO}_{4}\right)$, filtered, and concentrated under vacuum. This material was purified by column chromatography on silica gel (120 g column) using EtOAc / Hexanes (0:1 to 1:0) as eluent to give the product 12a (3.78 g, 79\% yield over 4 steps) after drying in a vacuum oven (set at $55^{\circ} \mathrm{C}$ ). Data as above. 


\section{SYNTHESIS OF BETA-LACTAM INTERMEDIATE 12B}

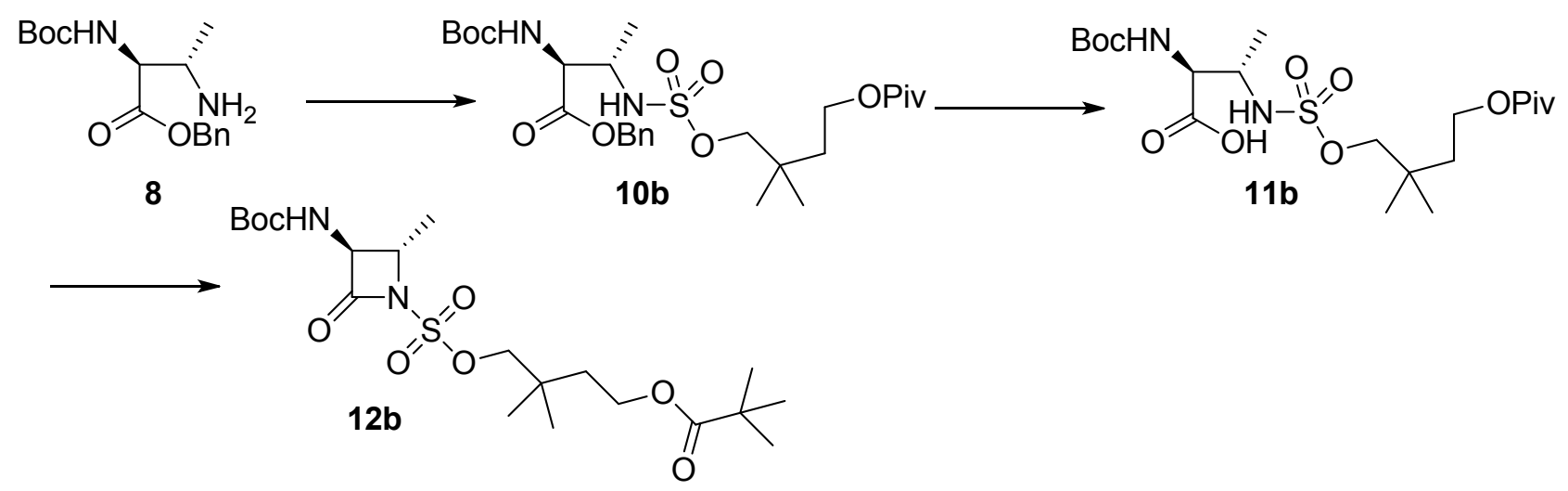

Preparation of Compound (2S,3S)-benzyl 2-((tert-butoxycarbonyl)amino)-3-(((2,2dimethyl-4-(pivaloyloxy)butoxy)sulfonyl)amino)butanoate $10 \mathrm{~b}$

A solution of (2S,3S)-benzyl 3-amino-2-((tert-butoxycarbonyl)amino)butanoate 8 (2.7 g, $8.76 \mathrm{mmol})$ in DCE $(25 \mathrm{~mL})$ was treated with saturated aq. $\mathrm{NaHCO}_{3}(29 \mathrm{~mL})$ and $\mathrm{TBAB}$ (284 $\mathrm{mg}, 0.88 \mathrm{mmol}$ ). The mixture was warmed to $40{ }^{\circ} \mathrm{C}$ then a solution of 4((chlorosulfonyl)oxy)-3,3-dimethylbutyl pivalate 9b (3.95 g, $13.13 \mathrm{mmol})$ in DCE (4 mL) was added dropwise. The reaction was stirred rapidly overnight, then cooled to rt. The organic phase was isolated and dried $\left(\mathrm{NaSO}_{4}\right)$, filtered and concentrated under vacuum. The residue was purified by column chromatography on silica gel using EtOAc / DCM (0:1 to 7:93) as eluent to give the title compound $\mathbf{1 0 b}(2.07 \mathrm{~g}, 41 \%)$ as an oil.

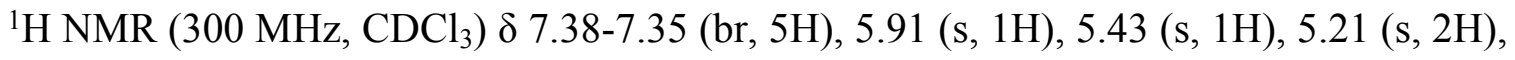
$4.53(\mathrm{q}, J=6.0 \mathrm{~Hz}, 1 \mathrm{H}) 4.12(\mathrm{q}, J=7.1 \mathrm{~Hz}, 2 \mathrm{H}), 3.99(\mathrm{~s}, 1 \mathrm{H}), 3.92-3.77(\mathrm{~m}, 2 \mathrm{H}), 1.65(\mathrm{t}$, $J=7.0 \mathrm{~Hz}, 2 \mathrm{H}), 1.44$ (s, 9H), $1.18(\mathrm{~s}, 9 \mathrm{H}), 1.12$ (d, $J=6.0 \mathrm{~Hz}, 3 \mathrm{H}), 0.99$ (d, $J=1.0 \mathrm{~Hz}$, $6 \mathrm{H})$.

Preparation of (2S,3S) 2-((tert-butoxycarbonyl)amino)-3-(((2,2-dimethyl-4(pivaloyloxy)butoxy)sulfonyl)amino)butanoic acid $11 \mathrm{~b}$

To a solution (2S,3S)-benzyl 2-((tert-butoxycarbonyl)amino)-3-(((2,2-dimethyl-4(pivaloyloxy)butoxy)sulfonyl)amino)butanoate $\mathbf{1 0 b}(2.07 \mathrm{~g}, 3.61 \mathrm{mmol})$ in EtOAc (18 $\mathrm{mL}$ ) was added $\mathrm{Pd} / \mathrm{C}\left(769 \mathrm{mg}, 10 \%\right.$ dry) under a $\mathrm{N}_{2}$ balloon. The $\mathrm{N}_{2}$ balloon was replaced with a $\mathrm{H}_{2}$ balloon, and the reaction mixture was evacuated under vacuum, then 
placed under $\mathrm{H}_{2}$ - this cycle was repeated $\mathrm{x} 3$. The reaction was then stirred for $2 \mathrm{~h}$ under $\mathrm{H}_{2}$ and monitor by TLC (5 : 95 EtOAc / DCM). The Pd/C was removed by filtration through a pad of Celite, and the filter cake was washed with EtOAc (x3). The solvent was removed under vacuum to give the crude product $11 \mathrm{~b}(1.66 \mathrm{~g})$. LCMS: $\mathrm{m} / z=483$ $[\mathrm{M}+\mathrm{H}]^{+}$

Preparation of 4-((((2S, 3S)-3-((tert-butoxycarbonyl)amino)-2-methyl-4-oxoazetidin-1yl)sulfonyl)oxy)-3,3-dimethylbutyl pivalate $12 \mathrm{~b}$

A solution of $\quad(2 S, 3 S) \quad 2-(($ tert-butoxycarbonyl)amino $)-3-(((2,2-$ dimethyl-4(pivaloyloxy)butoxy)sulfonyl)amino)butanoic acid 11b (1.66 g) in $\mathrm{MeCN}(100 \mathrm{~mL})$ was treated with $\mathrm{Et}_{3} \mathrm{~N}(1.05 \mathrm{~mL}, 7.57 \mathrm{mmol})$ at $0{ }^{\circ} \mathrm{C}$, followed by addition of TCFH $(1.45 \mathrm{~g}$, $5.16 \mathrm{mmol})$ in $\mathrm{MeCN}(15 \mathrm{~mL})$. The reaction was then stirred for $2 \mathrm{~h}$ at $\mathrm{rt}$ then concentrated under vacuum (Note: water bath temperature $<28{ }^{\circ} \mathrm{C}$ ). The residue was redissolved in DCM and then purified by column chromatography on silica gel using EtOAc / DCM (0:1 to 1:9) as eluent to give the title compound $\mathbf{1 2 b}(1.28 \mathrm{~g}, 80 \%$ for 2 steps).

${ }^{1} \mathrm{H}$ NMR $\left(300 \mathrm{MHz}, \mathrm{CDCl}_{3}\right) \delta 5.46(\mathrm{~d}, J=6.0 \mathrm{~Hz}, 1 \mathrm{H}), 4.35-4.08(\mathrm{~m}, 6 \mathrm{H}), 1.69(\mathrm{dt}, J=$ 7.0, 3.9 Hz, 2H), $1.62(\mathrm{~d}, J=6.0 \mathrm{~Hz}, 3 \mathrm{H}), 1.44$ (s, 9H), 1.19 (s, 9H), 1.04 (d, $J=4.1 \mathrm{~Hz}$, $6 \mathrm{H})$.

LCMS: $m / z=465[\mathrm{M}+\mathrm{H}]^{+}, 482[\mathrm{M}+\mathrm{H}+17]^{+}$. 


\section{SYNTHESIS OF BETA-LACTAM INTERMEDIATE 12C}

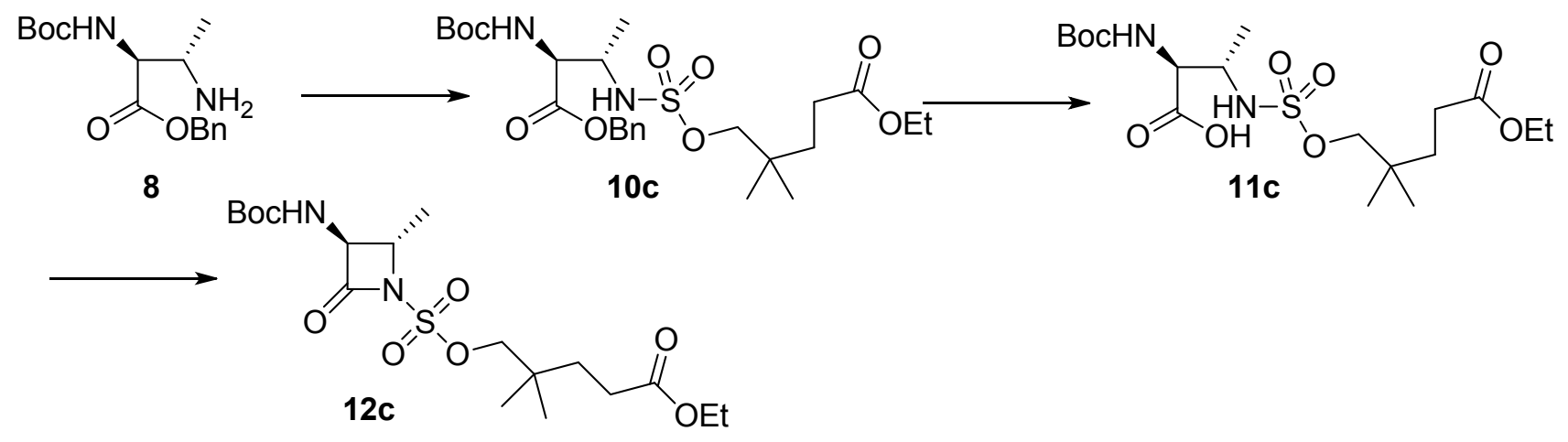

Preparation of (2S,3S)-2-tert-butoxycarbonylamino-3-[2-(2-methoxy-ethoxycarbonyl)2-methyl-propoxysulfonylamino]-butyric acid benzyl ester 10c

To a solution of $(2 S, 3 S)$-benzyl 3-amino-2-((tert-butoxycarbonyl)amino)butanoate 8 $(2.90 \mathrm{~g}, 9.39 \mathrm{mmol})$ in DCE $(15 \mathrm{~mL})$ was added a saturated aqueous solution of $\mathrm{NaHCO}_{3}$ $(15 \mathrm{~mL})$ and tetrabutylammonium bromide $(757 \mathrm{mg}, 2.35 \mathrm{mmol})$. To the solution was added 5-chlorosulfonyloxy-4,4-dimethyl-pentanoic acid ethyl ester 9c (5.12 g, 18.8 $\mathrm{mmol})$ in DCE $(15 \mathrm{~mL})$ at $0{ }^{\circ} \mathrm{C}$. The mixture was stirred at $0{ }^{\circ} \mathrm{C}$ for $2 \mathrm{~h}$ and warmed up to $\mathrm{rt}$ and stirred for $20 \mathrm{~h}$. The reaction mixture was diluted with DCM (50 mL) and washed with brine and $\mathrm{H}_{2} \mathrm{O}$. The organic phase was separated, dried $\left(\mathrm{Na}_{2} \mathrm{SO}_{4}\right)$, filtered and concentrated under vacuum. The residue was purified by column chromatography on silica gel using EtOAc / Hexanes (3:2) as eluent to give the title compound 10c (654 mg, $13 \%)$ as a colorless oil.

${ }^{1} \mathrm{H}-\mathrm{NMR}\left(300 \mathrm{MHz}, \mathrm{CDCl}_{3}\right) \delta$ 7.34-7.29 (m, 5H), 5.94-5.91 (m, 1H), 5.44-5.42 (m, 1H), $5.21(\mathrm{~s}, 2 \mathrm{H}), 4.55-4.52(\mathrm{~m}, 1 \mathrm{H}), 4.13$ (app. q, $J=6.9,5.4 \mathrm{~Hz}, 2 \mathrm{H}), 3.99-3.97(\mathrm{~m}, 1 \mathrm{H})$, 3.85-3.76 (m, 2H), 2.34-2.27 (m, 2H), 1.72-1.67 (m, 2H), $1.48(\mathrm{~s}, 9 \mathrm{H}), 1.26(\mathrm{t}, J=6.0$ $\mathrm{Hz}, 3 \mathrm{H}), 1.12$ (d, $J=7.2 \mathrm{~Hz}, 3 \mathrm{H}), 1.00(\mathrm{~s}, 6 \mathrm{H})$.

\section{Preparation of Compound 11c}

To a solution of $(2 S, 3 S)$-2-tert-butoxycarbonylamino-3-[2-(2-methoxy-ethoxycarbonyl)2-methyl-propoxysulfonylamino]-butyric acid benzyl ester 10c (5.18 g, $9.47 \mathrm{mmol})$ in EtOAc was added $\mathrm{Pd} / \mathrm{C}(500 \mathrm{mg})$. The suspension was degassed 3 times and refilled with hydrogen. The mixture was stirred under an atmosphere of $\mathrm{H}_{2}$ at $\mathrm{rt}$ for $2 \mathrm{~h}$. The mixture 
was filtered through a pad of Celite, and the filtrate was concentrated to under vacuum, affording the title compound 11c (4.23 g, 98\%).

LCMS: $m / z=457[\mathrm{M}+\mathrm{H}]^{+}$.

Preparation of ethyl 5-((((2S,3S)-3-((tert-butoxycarbonyl)amino)-2-methyl-4oxoazetidin-1-yl)sulfonyl)oxy)-4,4-dimethylpentanoate $12 \mathrm{c}$

To a solution of compound 11c $(1.16 \mathrm{~g}, 2.55 \mathrm{mmol})$ in $\mathrm{MeCN}(100 \mathrm{~mL})$ at $0{ }^{\circ} \mathrm{C}$ was added TCFH $(1.08 \mathrm{~g}, 3.82 \mathrm{mmol})$ and $\mathrm{Et}_{3} \mathrm{~N}(924 \mu \mathrm{L}, 6.63 \mathrm{mmol})$ at $0{ }^{\circ} \mathrm{C}$. The reaction was stirred at $0{ }^{\circ} \mathrm{C}$ for $10 \mathrm{~min}$ and then concentrated under vacuum. The residue was diluted to EtOAc $(200 \mathrm{~mL})$ and washed with $\mathrm{H}_{2} \mathrm{O}$ and brine. The organic phase was separated, dried, and concentrated under vacuum. The residue was purified by column chromatography on silica gel using EtOAc / Hexanes (3:2) as eluent to give the title compound 12c (905 mg, 82\%).

${ }^{1} \mathrm{H}-\mathrm{NMR}\left(300 \mathrm{MHz}, \mathrm{CDCl}_{3}\right) \delta$ 4.40-4.26 (m, 2H), 4.18-4.09 (m, 4H), 2.34-2.28 (m, 2H), 1.72-1.67 (m, 2H), $1.60(\mathrm{~d}, J=6.6 \mathrm{~Hz}, 3 \mathrm{H}), 1.44(\mathrm{~s}, 9 \mathrm{H}), 1.25$ (t, $J=6.9 \mathrm{~Hz}, 3 \mathrm{H}), 1.00$ (s, $3 \mathrm{H}), 0.98(\mathrm{~s}, 3 \mathrm{H})$.

LCMS: $m / z=437[\mathrm{M}+\mathrm{H}]^{+}$. 
SYNTHESIS OF FINAL PRODRUGS 27A TO 27C, 28A TO 28C AND 29B TO 29C
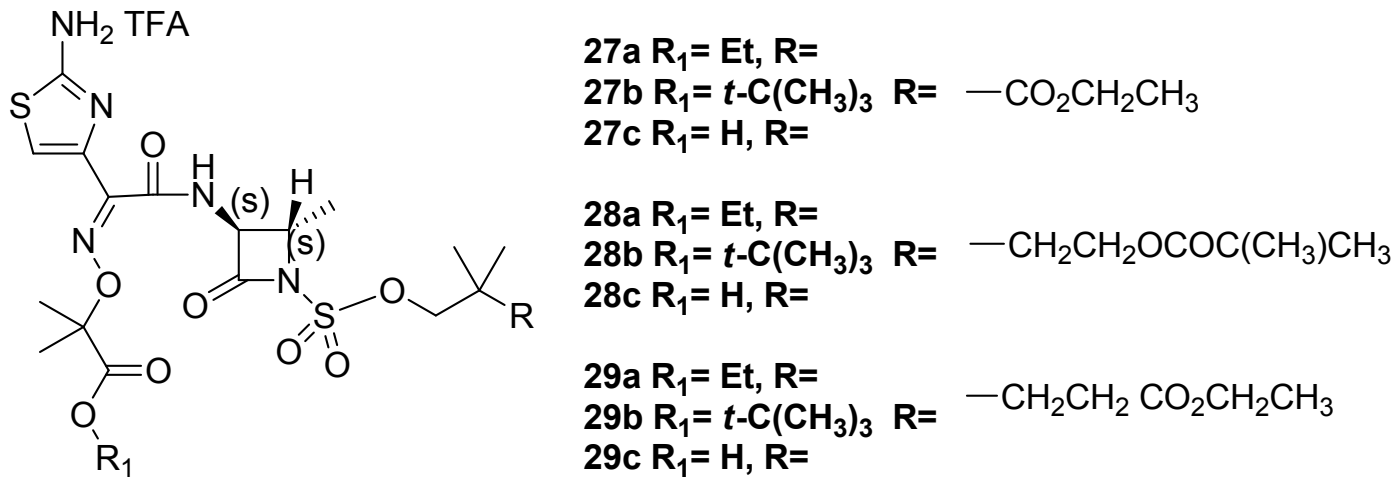

Part 1: General method of Boc deprotection

$\mathrm{MsOH}$.<smiles>[R]C(C)(C)COS(=O)(=O)N1C(=O)[C@@H](NC(=O)OCc2ccccc2)[SiH]1[CH]</smiles>

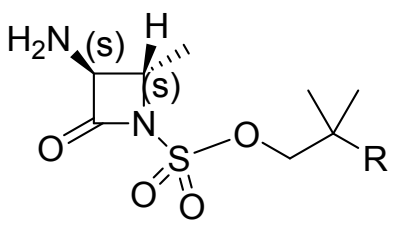

$12 \mathrm{a}-\mathrm{CO}_{2} \mathrm{CH}_{2} \mathrm{CH}_{3}$

$13 \mathrm{a}-\mathrm{CO}_{2} \mathrm{CH}_{2} \mathrm{CH}_{3}$

12b $-\mathrm{CH}_{2} \mathrm{CH}_{2} \mathrm{OCOC}\left(\mathrm{CH}_{3}\right)_{3}$

13b $-\mathrm{CH}_{2} \mathrm{CH}_{2} \mathrm{OCOC}\left(\mathrm{CH}_{3}\right)_{3}$

12c $-\mathrm{CH}_{2} \mathrm{CH}_{2} \mathrm{CO}_{2} \mathrm{CH}_{2} \mathrm{CH}_{3}$

13c $-\mathrm{CH}_{2} \mathrm{CH}_{2} \mathrm{CO}_{2} \mathrm{CH}_{2} \mathrm{CH}_{3}$

Preparation of 3-(3-amino-2-methyl-4-oxo-azetidine-1-sulfonyloxy)-2,2-dimethylpropionic acid ethyl ester methanesulfonic acid salt $13 a$

To a solution of 3-(3-tert-butoxycarbonylamino-2-methyl-4-oxo-azetidine-1sulfonyloxy)-2,2-dimethyl-propionic acid ethyl ester 12a (1.30 g, $3.44 \mathrm{mmol})$ in DCM $(15 \mathrm{~mL})$ was treated with $\mathrm{MsOH}(330 \mathrm{mg}, 3.44 \mathrm{mmol})$ at $\mathrm{rt}$ for $20 \mathrm{~h}$. The reaction mixture was concentrated to dryness and the residue was used in the next step without further purification.

LCMS: $m / z=309[\mathrm{M}+\mathrm{H}]^{+}$.

Preparation of 4-((((2S,3S)-3-amino-2-methyl-4-oxoazetidin-1-yl)sulfonyl)oxy)-3,3dimethylbutyl pivalate $13 b$ 
Undertaken on $1.24 \mathrm{~g}$. (no data).

Preparation of ethyl 5-((((2S,3S)-3-amino-2-methyl-4-oxoazetidin-1-yl)sulfonyl)oxy)4,4-dimethylpentanoate $13 c$

Undertaken on $905 \mathrm{mg}$.

LCMS: $m / z=337[\mathrm{M}+\mathrm{H}]^{+}$.

\section{Part 2: Synthesis of compound 26}

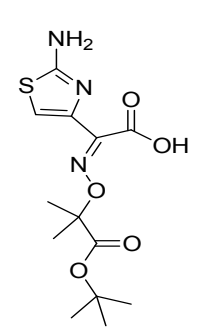

21

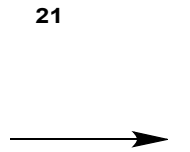

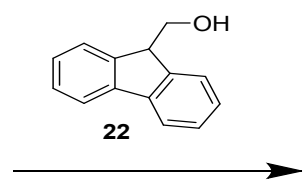

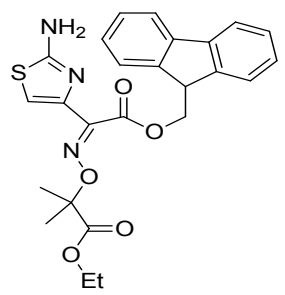

25
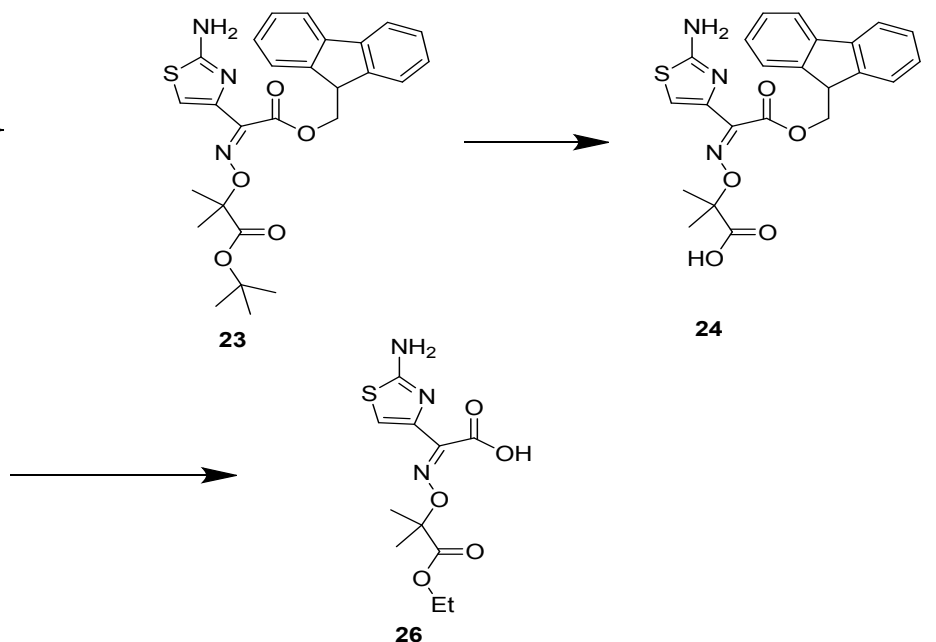

Preparation of 2-I(2-amino-thiazol-4-yl)-(9H-fluoren-9-ylmethoxycarbonyl)methyleneaminooxy]-2-methyl-propionic acid tert-butyl ester 23

To a suspension of 2-[(2-amino-thiazol-4-yl)-carboxy-methyleneaminooxy]-2-methylpropionic acid tert-butyl ester $(19.1 \mathrm{~g}, 57.9 \mathrm{mmol})$ in DCM $(200 \mathrm{~mL})$ was added $(9 \mathrm{H}$ fluoren-9-yl)-methanol (9.91 g, $57.9 \mathrm{mmol})$, EDCI (16.6 g, $86.9 \mathrm{mmol})$ and pyridine (14.0 mL, $174 \mathrm{mmol})$. The clear solution was stirred at $\mathrm{rt}$ as solid started to form. After 2$3 \mathrm{~h}$, the mixture was filtered and the solid was rinsed with DCM (30 mL), affording the title compound $\mathbf{2 3}(27.3 \mathrm{~g}, 93 \%)$ as a solid.

LCMS: $m / z=508.0[\mathrm{M}+\mathrm{H}]^{+}$

${ }^{1} \mathrm{H}-\mathrm{NMR}\left(300 \mathrm{MHz}, \mathrm{CDCl}_{3}\right) \delta 7.78(\mathrm{~d}, J=7.5 \mathrm{~Hz}, 2 \mathrm{H}), 7.72(\mathrm{~d}, J=7.8 \mathrm{~Hz}, 2 \mathrm{H}), 7.38(\mathrm{t}$, $J=7.5 \mathrm{~Hz}, 2 \mathrm{H}), 7.35$ (t, $J=7.5 \mathrm{~Hz}, 2 \mathrm{H}), 6.93$ (br. s, 2H), 6.41 (s, 1H), 4.62 (d, $J=6.9$ $\mathrm{Hz}, 2 \mathrm{H}), 4.33(\mathrm{t}, J=7.2 \mathrm{~Hz}, 1 \mathrm{H}), 1.58(\mathrm{~s}, 6 \mathrm{H}), 1.56(\mathrm{~s}, 9 \mathrm{H})$ 
${ }^{1} \mathrm{H}-\mathrm{NMR}\left(300 \mathrm{MHz}, d_{6}\right.$-DMSO), $\delta 7.88$ (d, $\left.J=7.2 \mathrm{~Hz}, 2 \mathrm{H}\right), 7.73$ (d, $\left.J=7.8 \mathrm{~Hz}, 2 \mathrm{H}\right)$, $7.41(\mathrm{t}, J=7.4 \mathrm{~Hz}, 2 \mathrm{H}), 7.33-7.30(\mathrm{~m}, 4 \mathrm{H}), 6.55(\mathrm{~s}, 1 \mathrm{H}), 4.64(\mathrm{~d}, J=6.3 \mathrm{~Hz}, 2 \mathrm{H}), 4.32(\mathrm{t}$, $J=6.5 \mathrm{~Hz}, 1 \mathrm{H}), 1.35(\mathrm{~s}, 15 \mathrm{H})$

${ }^{13} \mathrm{C}-\mathrm{NMR}\left(75 \mathrm{MHz}, d_{6}\right.$-DMSO), $\delta$ 172.1, 169.3, 162.9, 147.0, 143.8, 141.5, 141.2, 128.3, $127.6,125.7,120.7,109.5,82.9,81.0,67.0,46.6,28.0,24.0$.

Preparation of 2-\{(9H-fluoren-9-ylmethoxycarbonyl)-[2-(2,2,2-trifluoro-acetylamino)thiazol-4-yl]-methyleneaminooxy\}-2-methyl-propionic acid TFA salt 24

A solution of 2-[(2-amino-thiazol-4-yl)-(9H-fluoren-9-ylmethoxycarbonyl)methyleneaminooxy]-2-methyl-propionic acid tert-butyl ester 23 (27.3 g, $53.8 \mathrm{mmol})$ in TFA $(50 \mathrm{~mL})$ was stirred at $\mathrm{rt}$ for $2 \mathrm{~h}$. The reaction mixture was concentrated to dryness. The residue was triturated with $\mathrm{Et}_{2} \mathrm{O}(200 \mathrm{~mL})$ and filtered to afford the title compound $24(29.3 \mathrm{~g}, 100 \%)$ as a solid.

LCMS: $m / z=452.2[\mathrm{M}+\mathrm{H}]^{+}$

${ }^{1} \mathrm{H}-\mathrm{NMR}\left(300 \mathrm{MHz}, \mathrm{CDCl}_{3}\right) \delta 7.72(\mathrm{~d}, J=7.5 \mathrm{~Hz}, 2 \mathrm{H}), 7.62(\mathrm{~d}, J=7.5 \mathrm{~Hz}, 2 \mathrm{H}), 7.34(\mathrm{t}$, $J=7.5 \mathrm{~Hz}, 2 \mathrm{H}), 7.28(\mathrm{t}, J=7.5 \mathrm{~Hz}, 2 \mathrm{H}), 6.08(\mathrm{~s}, 1 \mathrm{H}), 4.71(\mathrm{~d}, J=6.6 \mathrm{~Hz}, 2 \mathrm{H}), 4.28(\mathrm{t}, J$ $=6.6 \mathrm{~Hz}, 1 \mathrm{H}), 1.56(\mathrm{~s}, 6 \mathrm{H})$

${ }^{1} \mathrm{H}-\mathrm{NMR}\left(300 \mathrm{MHz}, d_{6}\right.$-DMSO) $\delta 7.88(\mathrm{~d}, J=7.5 \mathrm{~Hz}, 2 \mathrm{H}), 7.73(\mathrm{~d}, J=7.5 \mathrm{~Hz}, 2 \mathrm{H}), 7.41$ (t, $J=7.4 \mathrm{~Hz}, 2 \mathrm{H}), 7.31(\mathrm{t}, J=7.4 \mathrm{~Hz}, 2 \mathrm{H}), 6.54(\mathrm{~s}, 1 \mathrm{H}), 4.66(\mathrm{~d}, J=6.6 \mathrm{~Hz}, 2 \mathrm{H}), 4.33$ (t, $J=6.5 \mathrm{~Hz}, 1 \mathrm{H}), 1.35(\mathrm{~s}, 6 \mathrm{H})$

${ }^{13} \mathrm{C}-\mathrm{NMR}\left(75 \mathrm{MHz}, d_{6}\right.$-DMSO) $\delta 174.7,169.5,162.6,146.2,143.8,141.2,140.2,128.3$, $127.7,125.7,120.6,110.3,82.6,67.1,46.6,24.1$.

Preparation of 2-I(2-amino-thiazol-4-yl)-(9H-fluoren-9-ylmethoxycarbonyl)methyleneaminooxy]-2-methyl-propionic acid ethyl ester 25

To a suspension of 2-\{(9H-fluoren-9-ylmethoxycarbonyl)-[2-(2,2,2-trifluoroacetylamino)-thiazol-4-yl]-methyleneaminooxy -2-methyl-propionic acid TFA salt 24 $(9.02 \mathrm{~g}, 16.0 \mathrm{mmol})$ in DCM $(200 \mathrm{~mL})$ and EtOH $(5 \mathrm{~mL})$ at $0{ }^{\circ} \mathrm{C}$ was added EDCI (4.60 $\mathrm{g}, 24.0 \mathrm{mmol})$ and pyridine $(6.47 \mathrm{~mL}, 80.0 \mathrm{mmol})$. The clear solution was allowed to warm to $\mathrm{rt}$ and stirred for $18 \mathrm{~h}$. The mixture was washed with saturated $\mathrm{NaHCO}_{3}$ and $\mathrm{H}_{2} \mathrm{O}$. The organic phase was separated, dried, and concentrated to dryness. The residue 
was purified by flash column chromatography ( silica, Hexanes / EtOAc $=2: 1$ ) to afford the title compound 25 (3.50 g, 46\%).

${ }^{1} \mathrm{H}-\mathrm{NMR}\left(300 \mathrm{MHz}, \mathrm{CDCl}_{3}\right) \delta 7.76(\mathrm{~d}, J=7.5 \mathrm{~Hz}, 2 \mathrm{H}), 7.72(\mathrm{~d}, J=7.5 \mathrm{~Hz}, 2 \mathrm{H}), 7.41$ (t, $J=7.5 \mathrm{~Hz}, 2 \mathrm{H}), 7.34(\mathrm{t}, J=7.5 \mathrm{~Hz}, 2 \mathrm{H}), 6.58(\mathrm{~s}, 1 \mathrm{H}), 6.22$ (br. s, 2H), 4.62 (d, $J=6.9$ $\mathrm{Hz}, 2 \mathrm{H}), 4.31(\mathrm{t}, J=7.2 \mathrm{~Hz}, 1 \mathrm{H}), 4.22(\mathrm{dd}, J=7.5,6.9 \mathrm{~Hz}, 2 \mathrm{H}), 1.56(\mathrm{~s}, 6 \mathrm{H}), 1.24(\mathrm{t}, J=$ $7.5 \mathrm{~Hz}, 3 \mathrm{H})$.

Preparation of 2-[(2-amino-thiazol-4-yl)-carboxy-methyleneaminooxy]-2-methylpropionic acid ethyl ester 26

To a solution of 2-[(2-amino-thiazol-4-yl)-(9H-fluoren-9-ylmethoxycarbonyl)methyleneaminooxy]-2-methyl-propionic acid ethyl ester 25 (1.84 g, $3.84 \mathrm{mmol})$ in DCM $(20 \mathrm{~mL})$ was treated with piperidine $(654 \mathrm{mg}, 7.68 \mathrm{mmol})$. The reaction mixture was stirred at $\mathrm{rt}$ for $3 \mathrm{~h}$, then concentrated to dryness. The residue was purified by preparative HPLC to give the title compound $26(1.17 \mathrm{~g}, 73 \%)$ as a solid.

${ }^{1} \mathrm{H}-\mathrm{NMR}\left(300 \mathrm{MHz}, \mathrm{CDCl}_{3}\right) \delta 6.78(\mathrm{~s}, 1 \mathrm{H}), 4.16(\mathrm{dd}, J=7.5,6.9 \mathrm{~Hz}, 2 \mathrm{H}), 1.57(\mathrm{~s}, 6 \mathrm{H})$, $1.24(\mathrm{t}, J=7.5 \mathrm{~Hz}, 3 \mathrm{H})$.

Part 3: General method for the synthesis of finals compounds, illustrated for compounds 27 a to 27 c

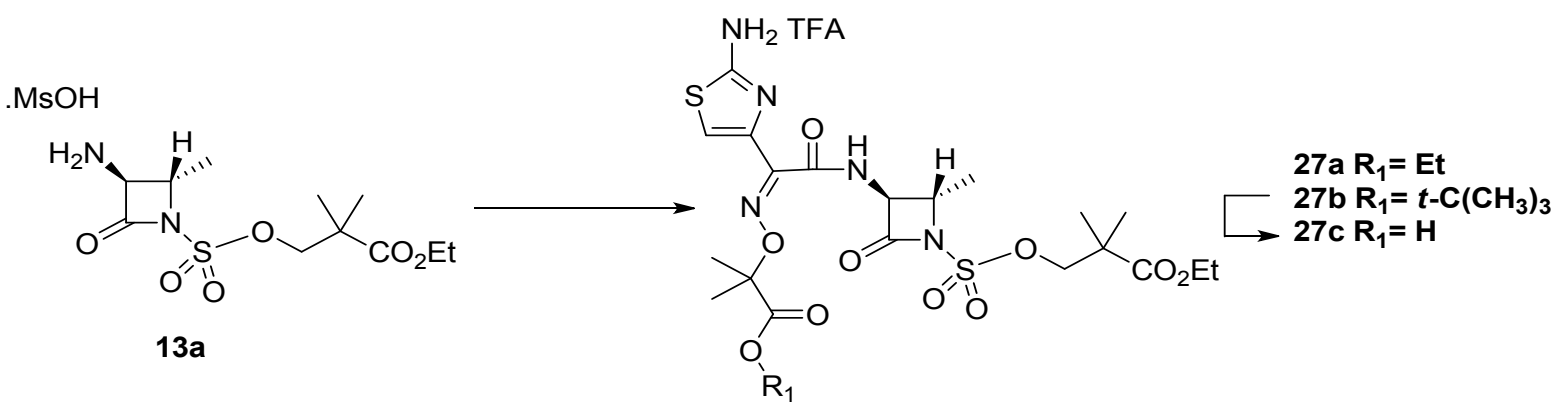

Preparation of ethyl 3-((((2S,3S)-3-((Z)-2-(2-aminothiazol-4-yl)-2-(((1-ethoxy-2methyl-1-oxopropan-2-yl)oxy)imino)acetamido)-2-methyl-4-oxoazetidin-1yl)sulfonyl)oxy)-2,2-dimethylpropanoate TFA salt 27 a 
To a solution of 3-(3-amino-2-methyl-4-oxo-azetidine-1-sulfonyloxy)-2,2-dimethylpropionic acid ethyl ester methanesulfonic acid salt 13a $(1.19 \mathrm{~g}, 2.95 \mathrm{mmol})$ and 2-[(2amino-thiazol-4-yl)-carboxy-methyleneaminooxy]-2-methyl-propionic acid ethyl ester $\mathbf{2 6}$ $(1.22 \mathrm{~g}, 2.95 \mathrm{mmol})$ in DCM $(100 \mathrm{~mL})$ was added EDCI $(847 \mathrm{mg}, 4.43 \mathrm{mmol})$ at $0{ }^{\circ} \mathrm{C}$. The reaction was stirred for $10 \mathrm{~min}$ and concentrated to dryness. The residue was purified by preparative HPLC to give the title compound $27 \mathrm{a}(1.20 \mathrm{~g}, 58 \%)$ as a solid.

LCMS: $m / z=592[\mathrm{M}+\mathrm{H}]^{+}$

${ }^{1} \mathrm{H}-\mathrm{NMR}\left(300 \mathrm{MHz}, \mathrm{CDCl}_{3}\right.$ ) $\delta$ 9.38-9.25 (br. s, 2H), 9.12 (d, $\left.J=6.9 \mathrm{~Hz}, 1 \mathrm{H}\right), 7.33$ (s, 1H), 4.53-4.40 (m, 4H), 4.25-4.11 (m, 4H), 1.73 (s, 3H), 1.65 (d, $J=6.9 \mathrm{~Hz}, 3 \mathrm{H}), 1.28-$ $1.23(\mathrm{~m}, 6 \mathrm{H})$

${ }^{1} \mathrm{H}-\mathrm{NMR}\left(300 \mathrm{MHz}, \mathrm{CD}_{3} \mathrm{OD}\right) \delta 7.02(\mathrm{~s}, 1 \mathrm{H}), 4.58(\mathrm{~d}, J=3.5 \mathrm{~Hz}, 1 \mathrm{H}), 4.51-4.42(\mathrm{~m}, 2 \mathrm{H})$, $4.38(\mathrm{~d}, J=9.1 \mathrm{~Hz}, 1 \mathrm{H}), 4.23-4.04(\mathrm{~m}, 4 \mathrm{H}), 1.62-1.51(\mathrm{~m}, 9 \mathrm{H}), 1.29-1.14(\mathrm{~m}, 12 \mathrm{H})$

${ }^{13} \mathrm{C}-\mathrm{NMR}\left(75 \mathrm{MHz}, \mathrm{CDCl}_{3}\right) \delta 174.9,174.4,170.7,162.7,159.6,141.7,132.5,117.9$, $114.1,110.2,85.3,63.5,62.3,61.5,59.2,42.9,23.7,22.0,17.9,14.2,14.1$

HRMS (ESI): $[\mathrm{M}+\mathrm{H}]+$ calc'd for $\mathrm{C}_{22} \mathrm{H}_{33} \mathrm{~N}_{5} \mathrm{O}_{10} \mathrm{~S}_{2} \mathrm{~m} / \mathrm{z}$ 592.1747, found 592.1743 .

Preparation of 2-(((Z)-(1-(2-aminothiazol-4-yl)-2-(((2S,3S)-1-((3-ethoxy-2,2-dimethyl3-oxopropoxy)sulfonyl)-2-methyl-4-oxoazetidin-3-yl)amino)-2-

oxoethylidene)amino)oxy)-2-methylpropanoic acid TFA salt $27 \mathrm{~b}$

To a solution of 3-(3-amino-2-methyl-4-oxo-azetidine-1-sulfonyloxy)-2,2-dimethylpropionic acid ethyl ester methane sulfonic acid salt 13a (1.06 g, $3.44 \mathrm{mmol})$ and 2-[(2amino-thiazol-4-yl)-carboxy-methyleneaminooxy]-2-methyl-propionic acid tert-butyl ester 21 (1.13 g, $3.44 \mathrm{mmol})$ in DCM (140 mL) was added EDCI (988 mg, $5.16 \mathrm{mmol})$ at $0{ }^{\circ} \mathrm{C}$ for $10 \mathrm{~min}$. The reaction was concentrated to dryness and the residue was purified by preparative HPLC to give the title compound $\mathbf{2 7 b}(783 \mathrm{mg}, 37 \%)$ as a solid.

${ }^{1} \mathrm{H}-\mathrm{NMR}\left(300 \mathrm{MHz}, \mathrm{CDCl}_{3}\right) \delta 9.15(\mathrm{~d}, J=6.9 \mathrm{~Hz}, 1 \mathrm{H}), 7.35(\mathrm{~s}, 1 \mathrm{H}), 4.57-4.41(\mathrm{~m}, 4 \mathrm{H})$, $4.16(\mathrm{dd}, J=7.2,6.9 \mathrm{~Hz}, 2 \mathrm{H}), 1.72-1.68(\mathrm{~m}, 9 \mathrm{H}), 1.46(\mathrm{~s}, 9 \mathrm{H}), 1.28-1.24(\mathrm{~m}, 9 \mathrm{H})$ ${ }^{1} \mathrm{H}-\mathrm{NMR}\left(300 \mathrm{MHz}, \mathrm{CD}_{3} \mathrm{OD}\right) \delta 7.03$ (s, 1H), 4.57 (d, J=3.5 Hz, 1H), 4.49-4.42 (m, 2H), $4.37(\mathrm{~d}, J=9.1 \mathrm{~Hz}, 1 \mathrm{H}), 4.10(\mathrm{q}, J=7.1 \mathrm{~Hz}, 2 \mathrm{H}), 1.54$ (d, $J=8.3 \mathrm{~Hz}, 9 \mathrm{H}), 1.41(\mathrm{~s}, 9 \mathrm{H})$, $1.27-1.13(\mathrm{~m}, 9 \mathrm{H})$ 
${ }^{13} \mathrm{C}-\mathrm{NMR}\left(75 \mathrm{MHz}, \mathrm{CDCl}_{3}\right) \delta 175.0,173.7,170.6,162.6,159.6,141.5,132.5,117.8$, $113.9,110.2,85.6,83.4,63.6,61.5,59.1,43.1,27.9,23.7,23.4,22.0,18.0,14.2$ HRMS (ESI): $[\mathrm{M}+\mathrm{H}]+$ calc'd for $\mathrm{C}_{24} \mathrm{H}_{37} \mathrm{~N}_{5} \mathrm{O}_{10} \mathrm{~S}_{2} \mathrm{~m} / \mathrm{z} 620.2060$, found 620.2085.

Preparation of 2-(((Z)-(1-(2-aminothiazol-4-yl)-2-(((2S,3S)-1-((3-ethoxy-2,2-dimethyl3-oxopropoxy)sulfonyl)-2-methyl-4-oxoazetidin-3-yl)amino)-2oxoethylidene)amino)oxy)-2-methylpropanoic acid TFA salt 27c

A sample of the above reaction mixture to form compound $27 \mathbf{b}$ was slowly added to a solution of TFA/DCM $(15 / 100,8.7 \mathrm{~mL} / 58 \mathrm{~mL})$ at $\mathrm{rt}$. The reaction was stirred for 2-3 $\mathrm{h}$ and monitored by LCMS. When completed, the reaction was concentrated in vacuo and the residue dissolved in MeCN and purified by preparative HPLC using 10-100\% MeCN / $\mathrm{H}_{2} \mathrm{O}$ with $0.1 \%$ TFA (30 $\mathrm{min}$, flow rate $20 \mathrm{~mL} / \mathrm{min}$ ) to give the title compound $27 \mathrm{c}$ (0.77 $\mathrm{g}, 71 \%$ for 3 steps) as a solid.

LC-MS: $m / z=564[\mathrm{M}+\mathrm{H}]^{+}$

${ }^{1} \mathrm{H}-\mathrm{NMR}\left(300 \mathrm{MHz}, \mathrm{CDCl}_{3}\right) \delta 8.91(\mathrm{~s}, 1 \mathrm{H}), 7.83(\mathrm{~s}, 1 \mathrm{H}), 7.04(\mathrm{~s}, 1 \mathrm{H}), 4.51-4.46(\mathrm{~m}, 1 \mathrm{H})$, $4.40(\mathrm{dd}, J=27.7,9.1 \mathrm{~Hz}, 2 \mathrm{H}), 4.14$ (q, $J=7.1 \mathrm{~Hz}, 2 \mathrm{H}), 1.61$ (d, $J=9.9 \mathrm{~Hz}, 9 \mathrm{H}), 1.31$ $1.19(\mathrm{~m}, 9 \mathrm{H})$

${ }^{1} \mathrm{H}-\mathrm{NMR}\left(300 \mathrm{MHz}, \mathrm{CD}_{3} \mathrm{OD}\right) \delta 7.03(\mathrm{~s}, 1 \mathrm{H}), 4.59$ (d, $\left.J=3.5 \mathrm{~Hz}, 1 \mathrm{H}\right), 4.51-4.40(\mathrm{~m}, 2 \mathrm{H})$, $4.38(\mathrm{~d}, J=9.1 \mathrm{~Hz}, 1 \mathrm{H}), 4.11(\mathrm{q}, J=7.1 \mathrm{~Hz}, 2 \mathrm{H}), 1.64-1.47(\mathrm{~m}, 9 \mathrm{H}), 1.26-1.12(\mathrm{~m}, 9 \mathrm{H})$ ${ }^{13} \mathrm{C}-\mathrm{NMR}\left(75 \mathrm{MHz}, \mathrm{CDCl}_{3}\right) \delta 176.7,175.2,170.5,163.4,159.7,141.4,131.4,110.8$, $85.2,77.7,77.4,63.3,61.7,59.6,42.9,41.0,23.6,23.3,21.9,17.7,14.1$

HRMS (ESI): $[\mathrm{M}+\mathrm{H}]^{+}$calc'd for $\mathrm{C}_{20} \mathrm{H}_{29} \mathrm{~N}_{5} \mathrm{O}_{10} \mathrm{~S}_{2} \mathrm{~m} / \mathrm{z} 564.1434$, found 564.1470.

Part 4: Synthesis of finals compounds 28 a to $28 \mathrm{c}$ using the general methods outlined above 

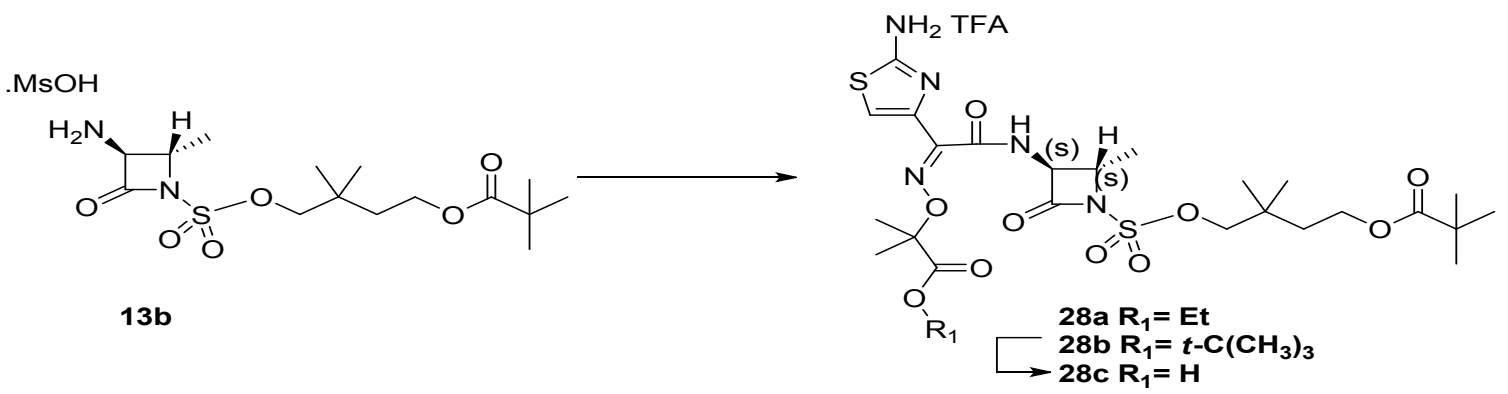

Preparation of 4-((((2S,3S)-3-((Z)-2-(2-aminothiazol-4-yl)-2-(((1-(tert-butoxy)-2methyl-1-oxopropan-2-yl)oxy)imino)acetamido)-2-methyl-4-oxoazetidin-1yl)sulfonyl)oxy)-3,3-dimethylbutyl pivalate TFA salt $28 a$

( $0.57 \mathrm{~g}, 59 \%$ for 2 steps $)$ as a solid.

LC-MS: $m / z=648[\mathrm{M}+\mathrm{H}]^{+}$

${ }^{1} \mathrm{H}-\mathrm{NMR}\left(300 \mathrm{MHz}, \mathrm{CDCl}_{3}\right) \delta 9.30(\mathrm{~s}, 2 \mathrm{H}), 8.94$ (d, $\left.J=7.1 \mathrm{~Hz}, 1 \mathrm{H}\right), 7.20(\mathrm{~s}, 1 \mathrm{H}), 5.55$ $(\mathrm{s}, 2 \mathrm{H}), 4.51(\mathrm{~m}, 1 \mathrm{H}), 4.37(\mathrm{q}, J=3.0 \mathrm{~Hz}, 1 \mathrm{H}), 4.30-4.07(\mathrm{~m}, 6 \mathrm{H}), 1.74-1.60(\mathrm{~m}, 9 \mathrm{H})$, $1.30(\mathrm{t}, J=6.0 \mathrm{~Hz}, 3 \mathrm{H}), 1.18(\mathrm{~s}, 9 \mathrm{H}), 1.05(\mathrm{~s}, 6 \mathrm{H})$

${ }^{19} \mathrm{~F}-\mathrm{NMR}\left(282 \mathrm{MHz}, \mathrm{CDCl}_{3}\right) \delta-76.0$

${ }^{13} \mathrm{C}-\mathrm{NMR}\left(75 \mathrm{MHz}, \mathrm{CDCl}_{3}\right) \delta 178.8,174.6,170.7,162.1,159.7,142.1,133.0,122.0$, $118.2,110.0,85.2,80.5,63.8,63.5,62.2,60.9,58.5,38.6,36.9,33.8,27.3,27.0,24.1$, $24.0,23.5,17.9,14.1$.

HRMS (ESI): $[\mathrm{M}+\mathrm{H}]+$ calc'd for $\mathrm{C}_{26} \mathrm{H}_{41} \mathrm{~N}_{5} \mathrm{O}_{10} \mathrm{~S}_{2} \mathrm{~m} / \mathrm{z}$ 648.2373, found 648.2399.

Preparation of 2-(((Z)-(1-(2-aminothiazol-4-yl)-2-(((2S,3S)-1-((2,2-dimethyl-4(pivaloyloxy)butoxy)sulfonyl)-2-methyl-4-oxoazetidin-3-yl)amino)-2-

oxoethylidene)amino)oxy)-2-methylpropanoic acid TFA salt $28 b$

(1.32 $\mathrm{g}, 73 \%$ for 2 steps) as a solid.

LCMS: $m / z=678[\mathrm{M}+\mathrm{H}]^{+}$

${ }^{1} \mathrm{H}-\mathrm{NMR}\left(300 \mathrm{MHz}, \mathrm{CDCl}_{3}\right) \delta 9.20(\mathrm{~s}, 1 \mathrm{H}), 9.14(\mathrm{~d}, J=7.1 \mathrm{~Hz}, 1 \mathrm{H}), 7.28(\mathrm{~s}, 1 \mathrm{H}), 4.53$ (ddd, $J=7.5,6.2,3.5 \mathrm{~Hz}, 1 \mathrm{H}), 4.35$ (dd, $J=7.1,3.5 \mathrm{~Hz}, 1 \mathrm{H}), 4.30-4.07$ (m, 4H), 1.79$1.60(\mathrm{~m}, 15 \mathrm{H}), 1.47(\mathrm{~s}, 9 \mathrm{H}), 1.25-1.14(\mathrm{~m}, 9 \mathrm{H}), 1.06(\mathrm{~s}, 6 \mathrm{H})$. 
Preparation of 2-(((Z)-(1-(2-aminothiazol-4-yl)-2-(((2S,3S)-1-((2,2-dimethyl-4(pivaloyloxy)butoxy)sulfonyl)-2-methyl-4-oxoazetidin-3-yl)amino)-2-

oxoethylidene)amino)oxy)-2-methylpropanoic $28 \mathrm{c}$

(1.14 g, 70\% over 3 steps) as a solid.

LCMS: $m / z=620[\mathrm{M}+\mathrm{H}]^{+}$

${ }^{1} \mathrm{H}-\mathrm{NMR}\left(300 \mathrm{MHz}, \mathrm{CDCl}_{3}\right.$ ) $\delta 9.08$ (br s, 2H), 7.09 (s, 10H), 4.49 (br, 2H), 4.33-4.03 (m, $4 \mathrm{H}), 1.92-1.55(\mathrm{~m}, 9 \mathrm{H}), 1.18(\mathrm{~s}, 9 \mathrm{H}), 1.05(\mathrm{~d}, J=1.7 \mathrm{~Hz}, 6 \mathrm{H})$

${ }^{1} \mathrm{H}-\mathrm{NMR}\left(300 \mathrm{MHz}, \mathrm{CD}_{3} \mathrm{OD}\right) \delta 7.03(\mathrm{~s}, 1 \mathrm{H}), 4.54(\mathrm{~d}, J=3.5 \mathrm{~Hz}, 1 \mathrm{H}), 4.48(\mathrm{dd}, J=6.2$, $3.5 \mathrm{~Hz}, 1 \mathrm{H}), 4.24(\mathrm{~d}, J=9.1 \mathrm{~Hz}, 1 \mathrm{H}), 4.15(\mathrm{~d}, J=9.2 \mathrm{~Hz}, 1 \mathrm{H}), 4.10$ (t, $J=6.3 \mathrm{~Hz}, 2 \mathrm{H})$, $1.66(\mathrm{t}, J=6.9 \mathrm{~Hz}, 2 \mathrm{H}), 1.51-1.59(\mathrm{~m}, 9 \mathrm{H}), 1.13$ (d, $J=1.9 \mathrm{~Hz}, 9 \mathrm{H}), 1.00(\mathrm{~s}, 6 \mathrm{H})$

${ }^{19} \mathrm{~F}-\mathrm{NMR}\left(282 \mathrm{MHz}, \mathrm{CDCl}_{3}\right) \delta-75.7$

${ }^{13} \mathrm{C}-\mathrm{NMR}\left(75 \mathrm{MHz}, \mathrm{CDCl}_{3}\right) \delta 179.6,170.5,162.9,159.3,141.4,131.5,110.9,80.5$, $63.31,61.3,59.3,38.7,36.8,33.8,27.1,24.1,24.0,23.6,23.0,17.8$

HRMS (ESI): $[\mathrm{M}+\mathrm{H}]+$ calc'd for $\mathrm{C}_{24} \mathrm{H}_{37} \mathrm{~N}_{5} \mathrm{O}_{10} \mathrm{~S}_{2} \mathrm{~m} / \mathrm{z}$ 620.2060, found 620.2085 .

Part 5: Synthesis of finals compounds $29 \mathrm{~b}$ to $29 \mathrm{c}$ using the general methods outlined above
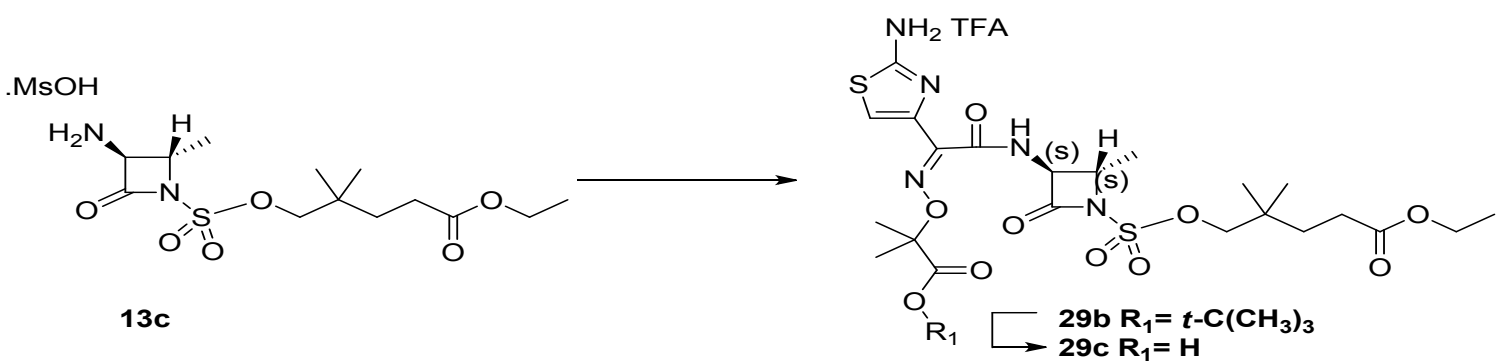

Note: compound 29a was not prepared

Preparation of ethyl 5-((((2S,3S)-3-((Z)-2-(2-aminothiazol-4-yl)-2-(((1-(tert-butoxy)-2methyl-1-oxopropan-2-yl)oxy)imino)acetamido)-2-methyl-4-oxoazetidin-1yl)sulfonyl)oxy)-4,4-dimethylpentanoate TFA salt $29 b$

$(1.21 \mathrm{~g}, 84 \%$ for 2 steps) as a solid. 
${ }^{1} \mathrm{H}-\mathrm{NMR}\left(300 \mathrm{MHz}, \mathrm{CDCl}_{3}\right) \delta 8.95(\mathrm{~d}, J=6.9 \mathrm{~Hz}, 1 \mathrm{H}), 7.33(\mathrm{~s}, 1 \mathrm{H}), 4.55-4.51(\mathrm{~m}, 1 \mathrm{H})$, 4.37-4.33 (m, 1H), 4.26-4.17 (m, 2H), 4.14-4.10 (m, 2H), 2.34-2.29 (m, 2H), 1.71-1.65 $(\mathrm{m}, 11 \mathrm{H}), 1.48(\mathrm{~s}, 9 \mathrm{H}), 1.26(\mathrm{t}, J=6.9 \mathrm{~Hz}, 3 \mathrm{H}), 0.99(\mathrm{~s}, 6 \mathrm{H})$.

Preparation of 2-(((Z)-(1-(2-aminothiazol-4-yl)-2-(((2S,3S)-1-(((5-ethoxy-2,2-dimethyl5-oxopentyl)oxy)sulfonyl)-2-methyl-4-oxoazetidin-3-yl)amino)-2-

oxoethylidene)amino)oxy)-2-methylpropanoic acid TFA salt 29c

(810 $\mathrm{mg}, 65 \%$ over 3 steps) as a solid.

LC-MS: $m / z=592[\mathrm{M}+\mathrm{H}]^{+}$

${ }^{1} \mathrm{H}-\mathrm{NMR}\left(300 \mathrm{MHz}, \mathrm{CDCl}_{3}\right) \delta 9.05(\mathrm{~d}, J=6.9 \mathrm{~Hz}, 1 \mathrm{H}), 7.15(\mathrm{~s}, 1 \mathrm{H}), 4.62-4.59(\mathrm{~m}, 1 \mathrm{H})$, 4.45-4.42 (m, 1H), 4.17-4.10 (m, 4H), 2.37-2.31 (m, 2H), 1.72-1.65 (m, 11H), $1.26(\mathrm{t}, J=$ $7.2 \mathrm{~Hz}, 3 \mathrm{H}), 0.99$ (s, 3H), 0.98 (s, 3H)

${ }^{1} \mathrm{H}-\mathrm{NMR}\left(300 \mathrm{MHz}, \mathrm{CD}_{3} \mathrm{OD}\right) \delta 7.03(\mathrm{~s}, 1 \mathrm{H}), 4.54(\mathrm{~d}, J=3.5 \mathrm{~Hz}, 1 \mathrm{H}), 4.42-4.52(\mathrm{~m}, 1 \mathrm{H})$, 4.19 (d, $J=9.2 \mathrm{~Hz}, 1 \mathrm{H}), 4.11$ (d, $J=9.1 \mathrm{~Hz}, 1 \mathrm{H}), 4.06$ (q, $J=7.1 \mathrm{~Hz}, 2 \mathrm{H}), 2.24-2.33$ (m, 2H), 1.59-1.67 (m, 2H), 1.50-1.59 (m, 9H), 1.19 (t, $J=7.1 \mathrm{~Hz}, 3 \mathrm{H}), 0.94$ (s, 6H)

${ }^{13} \mathrm{C}-\mathrm{NMR}\left(75 \mathrm{MHz}, \mathrm{CDCl}_{3}\right) \delta$ 176.6, 174.6, 170.5, 163.1, 159.6, 141.4, 131.4, 117.7, $113.8,85.1,80.5,61.0,34.0,33.1,29.2,23.4,17.9,17.6,14.2,13.9$

HRMS (ESI): $[\mathrm{M}+\mathrm{H}]+$ calc'd for $\mathrm{C}_{22} \mathrm{H}_{33} \mathrm{~N}_{5} \mathrm{O}_{10} \mathrm{~S}_{2} \mathrm{~m} / \mathrm{z} 592.1747$, found 592.1743 . 
Table S1. Stability of PRodrug 28C in 2.5\% ACETONitrile in 0.05 M Citrate BUFFER AT PH 4.7 AT $37^{\circ} \mathrm{C}$ (NO CES1).

\begin{tabular}{|c|c|c|c|c|c|c|c|}
\hline \multirow{2}{*}{ Prodrug } & \multicolumn{7}{|c|}{ Timepoint $^{\mathrm{a}}$} \\
\cline { 2 - 8 } & $\mathbf{0}$ min & $\mathbf{1}$ min & $\mathbf{2}$ min & $\mathbf{5}$ min & $\mathbf{1 0}$ min & $\mathbf{2 0}$ min & $\mathbf{3 0}$ min \\
\hline 28c & 100 & 94 & 94 & 95 & 87 & 66 & 54 \\
\hline
\end{tabular}

a Percentage of remaining prodrug when $0.5 \mathrm{mg}$ of prodrug $/ \mathrm{mL}$ of $2.5 \%$ acetonitrile in $0.05 \mathrm{M}$ citrate buffer at $\mathrm{pH} 4.7$ incubated at $37^{\circ} \mathrm{C}$ (percentage peak area by HPLC analysis).

TABLE S2. RELEASE OF AZTREONAM FROM PRODRUG 28C USING CES1

\begin{tabular}{|c|c|c|c|c|c|c|c|}
\hline \multirow{2}{*}{ Prodrug } & \multicolumn{7}{|c|}{ Timepoint after treatment with CES1a } \\
\cline { 2 - 8 } & $\mathbf{0}$ min & $\mathbf{1}$ min & $\mathbf{2}$ min & $\mathbf{5}$ min & $\mathbf{1 0}$ min & $\mathbf{2 0}$ min & $\mathbf{3 0}$ min \\
\hline $\mathbf{2 8 c}$ & $\mathrm{BQL}$ & 80 & $>95$ & $>95$ & $>95$ & $>95$ & $>95$ \\
\hline
\end{tabular}

a Percentage release of aztreonam when $0.5 \mathrm{mg}$ of prodrug / $\mathrm{mL}$ of $2.5 \%$ acetonitrile in $0.05 \mathrm{M}$ citrate buffer at $\mathrm{pH} 4.7$ incubated at $37{ }^{\circ} \mathrm{C}$ is treated with 150 Units / $\mathrm{mL}$ of CES1 enzyme (percentage peak area by HPLC analysis).

Conclusion from Tables S1 and S2: Prodrug 28c is stable in $2.5 \%$ acetonitrile in $0.05 \mathrm{M}$ citrate buffer for up to $30 \mathrm{~min}$ and releases aztreonam within $1 \mathrm{~min}$ when the buffer contains CES1 (full release of aztreonam within $2 \mathrm{~min}$ ). 
Table S3. Stability of prodrug 29c in $2.5 \%$ acetonitrile in $0.05 \mathrm{M}$ citrate buffer at pH 4.7 at $37^{\circ} \mathrm{C}$ (no CES1).

\begin{tabular}{|c|c|c|c|c|c|c|c|}
\hline \multirow{2}{*}{ Prodrug } & \multicolumn{7}{|c|}{ Timepoint $^{\mathrm{a}}$} \\
\cline { 2 - 8 } & $\mathbf{0}$ min & $\mathbf{1}$ min & $\mathbf{2}$ min & $\mathbf{5}$ min & $\mathbf{1 0}$ min & $\mathbf{2 0}$ min & $\mathbf{3 0}$ min \\
\hline 29c & 100 & 100 & 100 & 83 & 70 & 49 & 36 \\
\hline
\end{tabular}

a Percentage of remaining prodrug when $0.5 \mathrm{mg}$ of prodrug $/ \mathrm{mL}$ of $2.5 \%$ acetonitrile in $0.05 \mathrm{M}$ citrate buffer at $\mathrm{pH} 4.7$ incubated at $37^{\circ} \mathrm{C}$ (percentage peak area by HPLC analysis).

TABLE S4. RELEASE OF AZTREONAM FROM PRODRUG 29C USING CES1

\begin{tabular}{|c|c|c|c|c|c|c|c|}
\hline \multirow{2}{*}{ Prodrug } & \multicolumn{7}{|c|}{ Timepoint after treatment with CES1a } \\
\cline { 2 - 8 } & $\mathbf{0}$ min & $\mathbf{1}$ min & $\mathbf{2}$ min & $\mathbf{5}$ min & $\mathbf{1 0}$ min & $\mathbf{2 0}$ min & $\mathbf{3 0}$ min \\
\hline 29c & BQL & 24 & 45 & 76 & 86 & 90 & 90 \\
\hline
\end{tabular}

a Percentage release of aztreonam when $0.5 \mathrm{mg}$ of prodrug / $\mathrm{mL}$ of $2.5 \%$ acetonitrile in $0.05 \mathrm{M}$ citrate buffer at $\mathrm{pH} 4.7$ incubated at $37^{\circ} \mathrm{C}$ is treated with $150 \mathrm{U} / \mathrm{mL}$ of CES1 enzyme (percentage peak area by HPLC analysis).

Conclusion from Tables S3 and S4: Prodrug 29c is stable in $2.5 \%$ acetonitrile in $0.05 \mathrm{M}$ citrate buffer for up to $30 \mathrm{~min}$ and releases aztreonam within $1 \mathrm{~min}$ when the buffer contains CES1 (full release of aztreonam within $10 \mathrm{~min}$ ).

Conclusion from Tables S3 and S4: Prodrug 29c is stable in $2.5 \%$ acetonitrile in $0.05 \mathrm{M}$ citrate buffer 


\section{SYNTHESIS OF 3,3-DIMETHYLTETRAHYDROFURAN ${ }^{1}$}
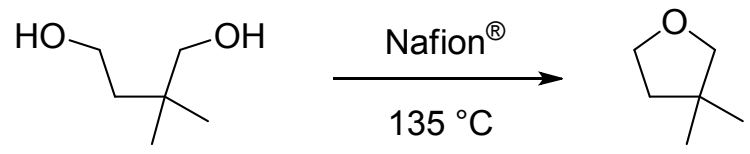

A flask equipped with a distillation head was charged with 2,2-dimethylbutane-1,4-diol $(1.0 \mathrm{~g}, 8.5 \mathrm{mmol})$ and $\mathrm{Nafion}^{\circledR}$ perfluorinated resin powder $(50 \mathrm{mg})$. The stirred mixture was heated to $135{ }^{\circ} \mathrm{C}$. As the reaction progressed, the product was collected as a distillate. The distillate was purified by a second distillation to give 3,3dimethyltetrahydrofuran as a clear and colorless liquid (286 mg, 33\% yield).

${ }^{1} \mathrm{H}-\mathrm{NMR}\left(300 \mathrm{MHz}, \mathrm{CDCl}_{3}\right) \delta 3.88$ (t, $\left.J=7.0 \mathrm{~Hz}, 2 \mathrm{H}\right), 3.43(\mathrm{~s}, 2 \mathrm{H}), 1.68$ (t, $J=7.3 \mathrm{~Hz}$, 2H), $1.09(\mathrm{~s}, 6 \mathrm{H})$.

${ }^{13} \mathrm{C}-\mathrm{NMR}\left(300 \mathrm{MHz}, \mathrm{CDCl}_{3}\right) \delta 80.4,67.9,40.8,39.2,26.2$.
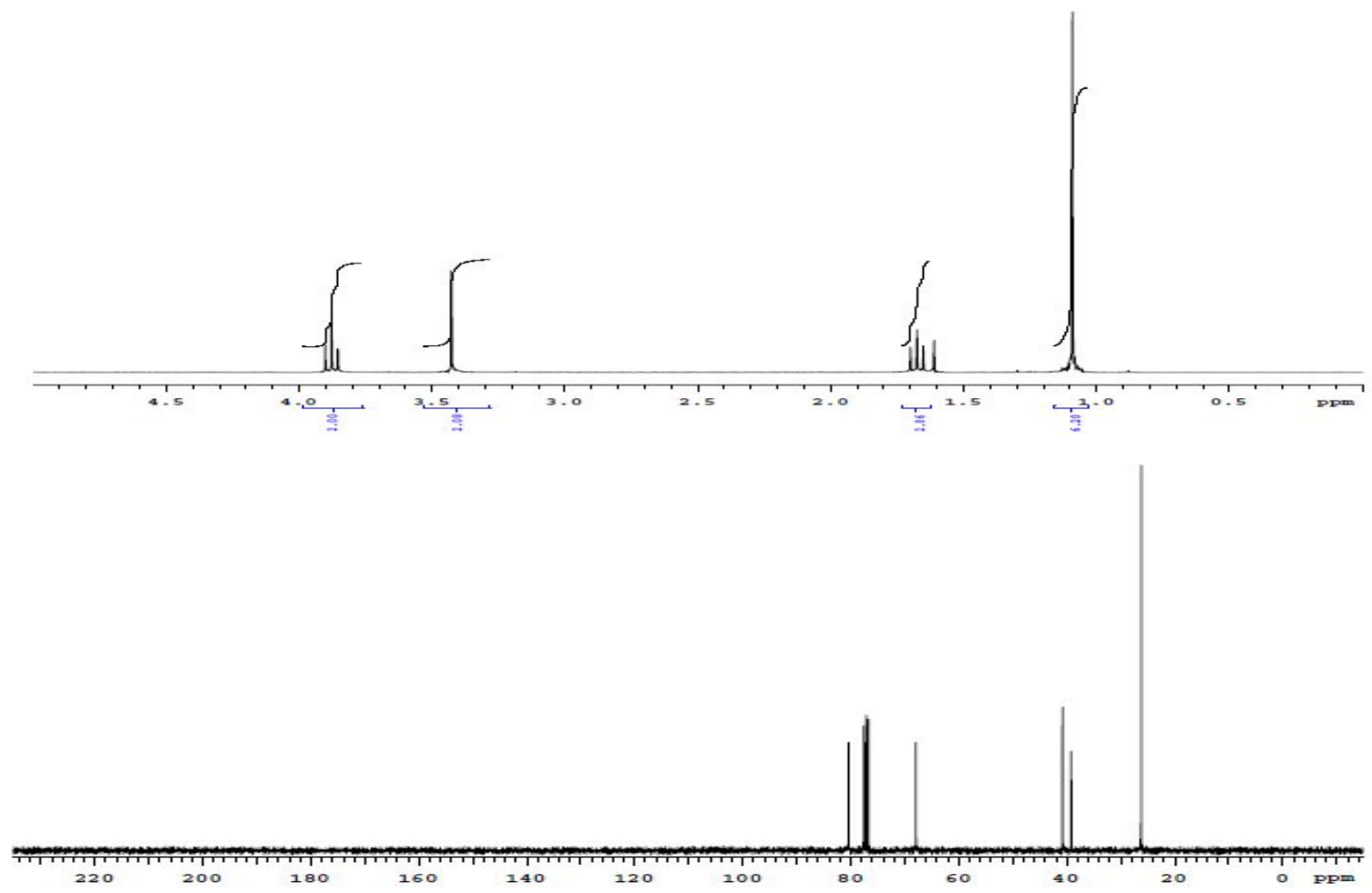

3,3-Dimethyltetrahydrofuran was used as a reference standard for ${ }^{1} \mathrm{H}-\mathrm{NMR}$ enzymatic release studies (detailed on pages S7-S8). 
1H-NMR STUDY 1: RELEASE OF 3,3-DIMETHYLTETRAHYDROFURAN AND AZTREONAM FROM PRODRUG 28C

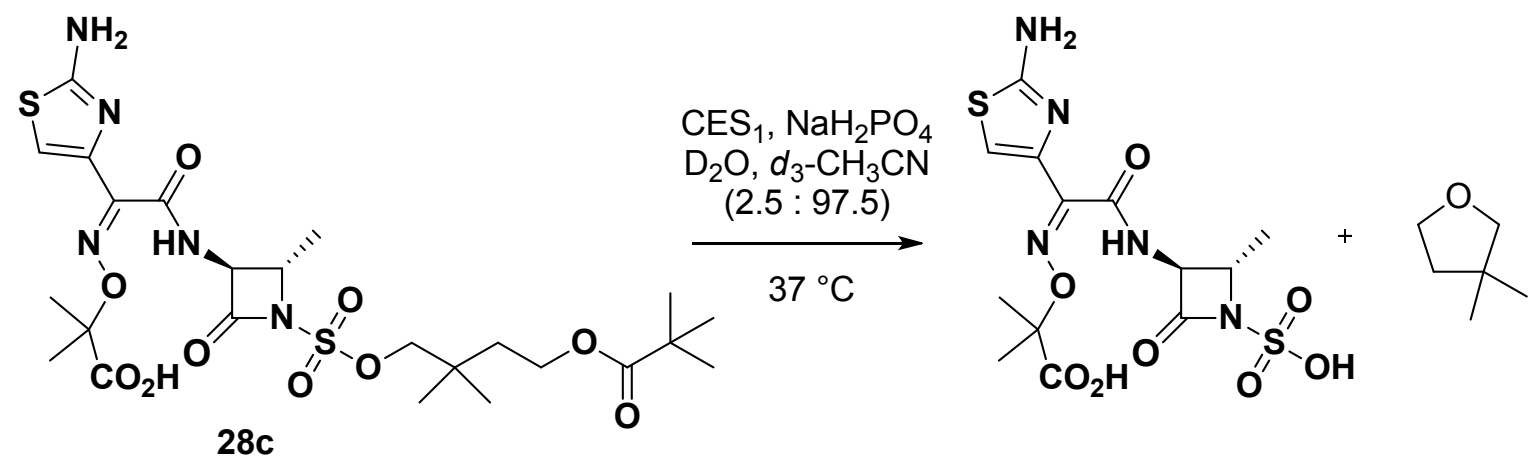

A stirring mixture of CES1 (20 mg, 2200 Units) in a $15 \mathrm{mM}$ solution of sodium phosphate monobasic (enzyme grade) in acetonitrile- $d_{3} / \mathrm{D}_{2} \mathrm{O}(1 \mathrm{~mL}$; ratio of 2.5 : 97.5) was heated at $37{ }^{\circ} \mathrm{C}$ for $5 \mathrm{~min}$. 2-(((Z)-(1-(2-aminothiazol-4-yl)-2-(((2S,3S)-1-((2,2dimethyl-4-(pivaloyloxy)butoxy)sulfonyl)-2-methyl-4-oxoazetidin-3-yl)amino)-2oxoethylidene)amino)oxy)-2-methylpropanoic acid TFA salt 28c (10 mg, $14 \mu \mathrm{mol})$ was added, and the suspension was stirred for $70 \mathrm{~min}$ at $37^{\circ} \mathrm{C}$. Over the course of the reaction a fine precipitate formed. The mixture was filtered through a $25 \mathrm{~mm}, 0.45 \mu \mathrm{M}$ glass fiber syringe filter (Pall Corporation Acrodisc). The filtrate was analyzed by ${ }^{1} \mathrm{H}-\mathrm{NMR}$ spectroscopy to reveal that 3,3-dimethyltetrahydrofuran was released as one of the products. The presence of 3,3-dimethyltetrahydrofuran was confirmed by ${ }^{1} \mathrm{H}-\mathrm{NMR}$ analysis of the same sample spiked with $2 \mu \mathrm{L}$ of authentic material.

Figure S1. ${ }^{1} \mathrm{H}-\mathrm{NMR}$ spectrum of reaction mixture after treatment of 28c with CES1.

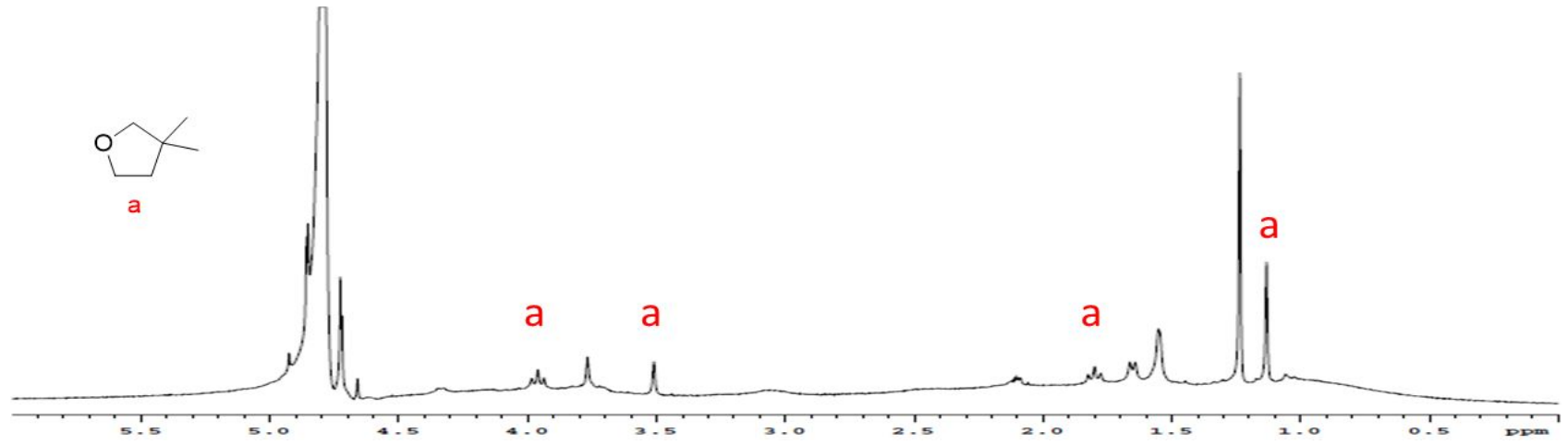


Figure S2. ${ }^{1} \mathrm{H}-\mathrm{NMR}$ spectrum of authentic 3,3-dimethyltetrahydrofuran (from synthesis on page S6).

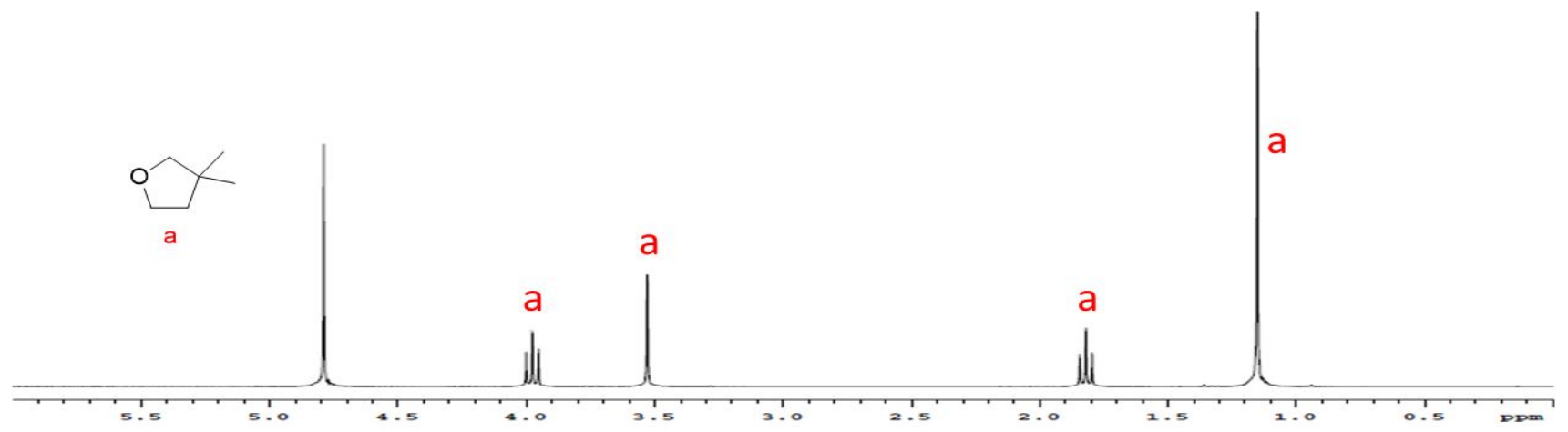

Figure S3. ${ }^{1} \mathrm{H}-\mathrm{NMR}$ spectrum of reaction mixture spiked with $2 \mu \mathrm{L}$ of 3,3dimethyltetrahydrofuran.

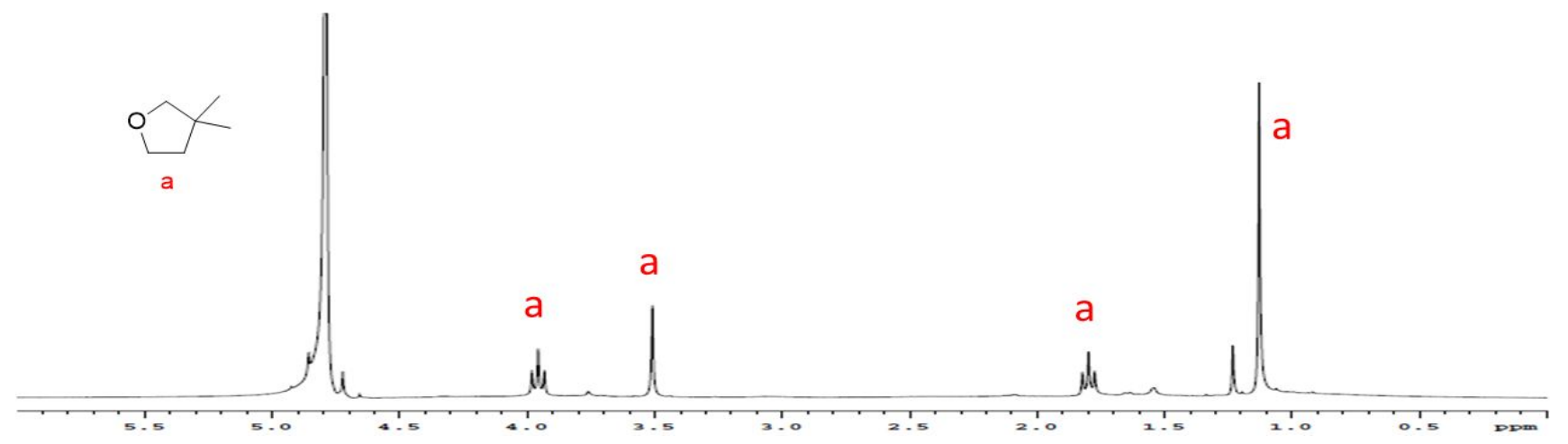


1H-NMR STUDY 2: RELEASE OF 5,5-DIMETHYLTETRAHYDRO-2H-PYRAN-2-ONE / 5HYDROXY-4,4-DIMETHYLPENTANOIC ACID AND AZTREONAM FROM COMPOUND 29C
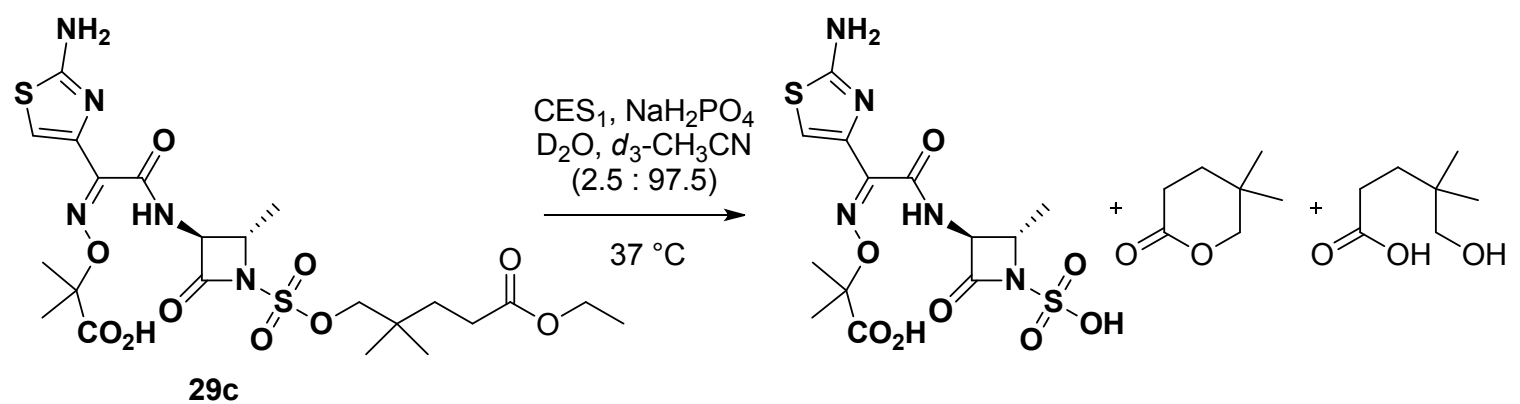

A stirring mixture of CES1 (20 mg, 2200 Units) in a $15 \mathrm{mM}$ solution of sodium phosphate monobasic (enzyme grade) in $2.5 \%$ acetonitrile- $d_{3} / \mathrm{D}_{2} \mathrm{O}(1 \mathrm{~mL})$ was heated at $37^{\circ} \mathrm{C}$ for 5 min. 2-(((Z)-(1-(2-aminothiazol-4-yl)-2-(((2S,3S)-1-(((5-ethoxy-2,2-dimethyl5-oxopentyl)oxy)sulfonyl)-2-methyl-4-oxoazetidin-3-yl)amino)-2-

oxoethylidene)amino)oxy)-2-methylpropanoic acid TFA salt 29c (10 mg, $14 \mu \mathrm{mol})$ was added, and the suspension was stirred for $19 \mathrm{~h}$ at $37{ }^{\circ} \mathrm{C}$. Over the course of the reaction a fine precipitate formed. The mixture was filtered through a $25 \mathrm{~mm}, 0.45 \mu \mathrm{M}$ glass fiber syringe filter (Pall Corporation Acrodisc). The filtrate was analyzed by ${ }^{1} \mathrm{H}-\mathrm{NMR}$ spectroscopy to reveal that 5,5-dimethyltetrahydro- $2 \mathrm{H}$-pyran-2-one and 5-hydroxy-4,4dimethylpentanoic acid were released from compound 29c. The presence of 5,5dimethyltetrahydro-2 $H$-pyran-2-one and 5-hydroxy-4,4-dimethylpentanoic acid were confirmed by ${ }^{1} \mathrm{H}-\mathrm{NMR}$ analysis of the same sample spiked with $2 \mathrm{mg}$ of authentic material (mixture of the two compounds).

Figure S4. ${ }^{1} \mathrm{H}-\mathrm{NMR}$ spectrum of reaction mixture after treatment of $29 \mathbf{c}$ with CES1.

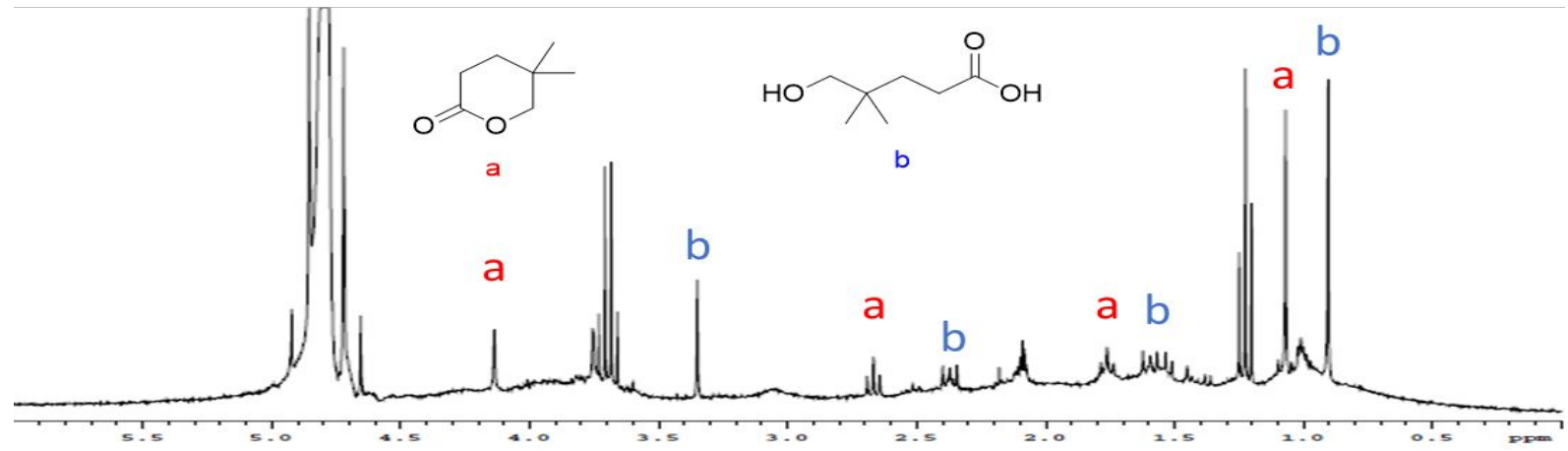


Figure S5. ${ }^{1} \mathrm{H}-\mathrm{NMR}$ spectrum of authentic 5,5-dimethyltetrahydro-2 $H$-pyran-2-one and 5-hydroxy-4,4-dimethylpentanoic acid mixture.

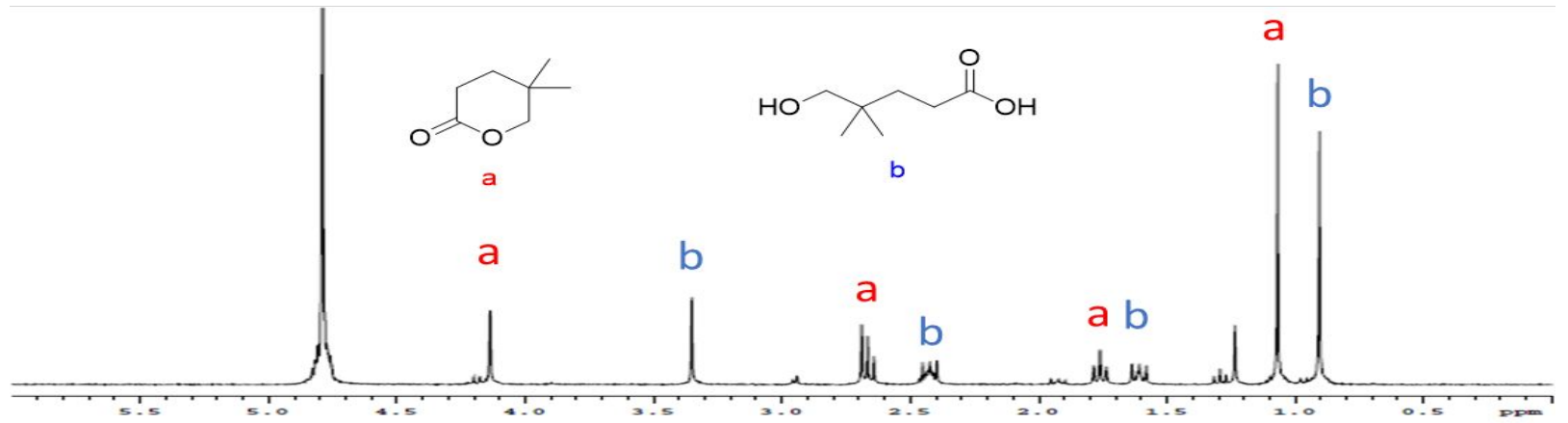

Figure S6. ${ }^{1} \mathrm{H}-\mathrm{NMR}$ spectrum of reaction mixture spiked with $2 \mathrm{mg}$ of a 5,5dimethyltetrahydro-2H-pyran-2-one and 5-hydroxy-4,4-dimethylpentanoic acid mixture.

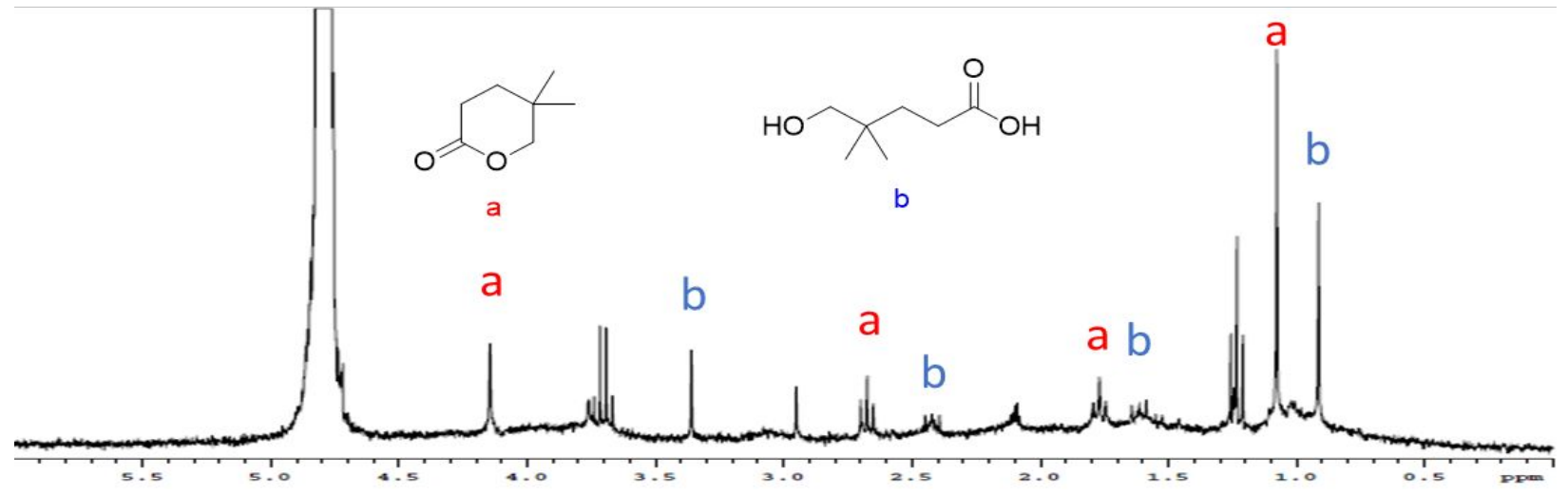




\section{REFERENCES}

1. Olah, G. A.; Fung, A. P.; Ripudaman, H. Synthesis 1981, 474-476. 